\title{
Diachronous evolution of Late Jurassic-Cretaceous continental rifting in the northeast Atlantic (west Iberian margin)
}

\author{
Tiago M. Alves, ${ }^{1}$ Carlos Moita, ${ }^{2}$ Tiago Cunha, ${ }^{3}$ Magnar Ullnaess, ${ }^{4}$ Reidun Myklebust,${ }^{4}$ \\ José H. Monteiro, ${ }^{3,5}$ and G. Manuppella ${ }^{6,7}$
}

Received 31 May 2008; revised 27 February 2009; accepted 7 April 2009; published 7 July 2009.

[1] Regional (2-D) seismic reflection profiles, outcrop, and borehole data are used to characterize the evolution of deep offshore sedimentary basins in southwest Iberia (Alentejo Basin). The interpreted data indicate the bulk of Late Jurassic-earliest Cretaceous subsidence occurred in the present-day continental slope area, as shown by (1) significant thickening of synrift strata basinward from a slopebounding fault system (SFS), west of which the total thickness of sediment can reach more than $9.0 \mathrm{~km}$, and (2) relatively thin Mesozoic strata east of the SFS, where thickening of synrift units against principal faults is limited. Five principal regressive events and their basal unconformities reflect tectonic uplift and relative emersion in proximal basins, which were located on the rift shoulder to subsiding tilt blocks west of the SFS. These regressive events are correlated with major rift-related events occurring on the deeper margin. Direct comparisons with the Peniche Basin of northwest Iberia reveal that significant portions of the Iberian lower plate margin were uplifted and eroded during the last stages of continental rifting. This process was repeated at different times (and in different areas) as the locus of rifting and continental breakup migrated northward. As a result, two distinct rift axes are recognized in west Iberia, a first axis extending from the Porto Basin to the Alentejo Basin and a second axis located on the outer proximal margin north of $38^{\circ} 30 \mathrm{~N}$. In addition, the SFS delimited (1) prograding deposits of Cretaceous-Paleogene age and (2) late Cenozoic deposits draping the modern continental slope. These

\footnotetext{
${ }^{1}$ 3DLab, School of Earth, Ocean and Planetary Sciences, Cardiff University, Cardiff, UK.

${ }^{2}$ Direcção Geral de Energia e Geologia, Divisão para a Pesquisa e Prospecção de Petróleo, Lisbon, Portugal.

${ }^{3}$ Department of Earth Sciences, Oxford University, Oxford, UK.

${ }^{4}$ TGS-NOPEC Geophysical Company, Asker, Norway.

${ }^{5}$ Now at Departamento de Geologia Marinha, Instituto Nacional de Engenharia, Tecnologia e Inovação, Amadora, Portugal.

${ }^{6}$ Departamento de Geologia, Instituto Nacional de Engenharia, Tecnologia e Inovação, Amadora, Portugal.

${ }^{7}$ Deceased 2004.

Copyright 2009 by the American Geophysical Union. 0278-7407/09/2008TC002337
}

latter facts demonstrate that on lower plate passive margins, the relative position of the continental slope is established during the final rifting episode(s) preceding continental breakup. Citation: Alves, T. M., C. Moita, T. Cunha, M. Ullnaess, R. Myklebust, J. H. Monteiro, and G. Manuppella (2009), Diachronous evolution of Late Jurassic-Cretaceous continental rifting in the northeast Atlantic (west Iberian margin), Tectonics, 28, TC4003, doi:10.1029/2008TC002337.

\section{Introduction}

[2] Passive continental margins record diachronous riftto-drift transitions, with transverse fault zones separating different segments of the crust with distinct breakup ages [Withjack et al., 1998; Bueno, 2004; Péron-Pinvidic et al., 2007]. Relative crustal stretching $(\beta)$, rift-related faulting and igneous activity vary significantly in each of the crustal segments [Welsink and Tankard, 2009] imposing disparities in regional thermal regimes prior to, during, and after continental breakup [Boillot and Froitzheim, 2001; Michon and Merle, 2003]. As a result, passive margins are commonly classified as "volcanic" or "nonvolcanic," depending on the relative expression of riftrelated igneous processes along them [Wilson et al., 2001; Tucholke and Sibuet, 2007]. When variations in the structure of crustal segments are considered across conjugate pairs of margins, the concepts of "upper plate" and "lower plate" margins are commonly evoked [Wernicke, 1985; Lister et al., 1986, 1991; Reston et al., 1995; Manatschal and Bernoulli, 1998; 1999]. On lower plate margins as west Iberia, sets of oceanward dipping extensional faults appear to detach downward into a pervasive detachment zone, the $\mathrm{S}$ or $\mathrm{H}$ reflector (e.g., Galician margin [Reston et al., 1995; Boillot and Froitzheim, 2001; Reston and Pérez-Gussinyé, 2007]). Lower plate margins are generally highly structured and preserve most of the rotational normal faults, tilt blocks and half grabens developed during continental rifting. In contrast, upper plate margins show a simpler geometry and comprise faulted basement rocks above a landward dipping detachment fault [Lister et al., 1986].

[3] Data acquired onshore [Wilson et al., 1989; Leinfelder and Wilson, 1998; Rasmussen et al., 1998; Alves et al., 2003b] and in the Iberia Abyssal Plain [Wilson et al., 1996, 2001; Tucholke and Sibuet, 2007], recently combined with high-quality seismic profiles on continental slope areas [Alves et al., 2006; Clark et al., 
2007], have provided significant advances on the mapping of the nonvolcanic margin of west Iberia. These works have recognized major changes in the geometry and total extension experienced by the upper crust across and along strike. Variations in the geometry of rift basins are particularly evident across distinct crustal segments separated by transfer faults, which were also important in accommodating oblique extension [Lister et al., 1986; Driscoll et al., 1995; Clark et al., 2007]. Nonetheless, the detailed evolution of continental rifting for the different crustal segments composing the west Iberian margin has not yet been documented. This comprises a major gap in knowledge, as the geometry of the margin, together with the degree and relative angle of stretching, are directly related to variations in basement subsidence rates during synrift extension [e.g., Boillot and Froitzheim, 2001; Sayers et al., 2001] and to the degree of deformation experienced in subsequent episodes of tectonic reactivation [Neves et al., 2009]. Also, the timing of continental rifting, the relative locations of continental breakup and the significance of synrift and postrift tectonics along the west Iberian margin are key issues not yet fully addressed, posing serious problems to the correct assessment of its hydrocarbon potential [Tankard and Welsink, 1987; Masson and Miles, 1986; Hiscott et al., 1990a; Alves et al., 2006]. Hence, this work tries to address the following questions:

[4] 1. What are the structure, extent and overall geometries of Mesozoic rift basins in southwest Iberia?

[5] 2. What is the tectonosedimentary evolution of proximal rift basins on a (nonvolcanic) lower plate margin?

[6] 3. What are the implications of Late JurassicCretaceous margin segmentation for hydrocarbon exploration in west Iberia?

[7] Seismic reflection, borehole, outcrop, time structure, isochron and isopach data are presented in order to clarify the tectonosedimentary evolution of the southwest Iberian margin (Alentejo Basin, Figure 1). This paper concludes that the geometry of Late Jurassic-Early Cretaceous rifting offshore west Iberia is similar to case studies in the Gulf of Suez and the Alps. However, stratigraphic unconformities marking episodes of tectonic uplift in shoulder areas from deep offshore extensional basins are used for the first time to characterize the rift-related evolution of the west Iberian margin. This approach includes the recognition of major structures controlling the evolution of lower plate margins during continental rifting. Finally, the tectonosedimentary evolution of west Iberia and its hydrocarbon potential is discussed at the end of this paper.

[8] The term lower plate margin is used in this work to define the broad geometry of deep offshore extensional basins in west Iberia, i.e., without implications for the precise geometry of an inferred detachment zone (S reflector) at depth, which comprise sets of rotated tilt blocks bounded by west dipping extensional faults generated during continental rifting [Alves et al., 2006; Afilhado et al., 2008; Tucholke and Whitmarsh, 2009] (Figure 1). This work follows the concepts of Driscoll et al. [1995] and Wilson et al. [2001] on the architecture of rift-related units on passive margins: (1) synrift units comprise strata deposited during the last extension episode leading to continental breakup and (2) postrift strata are deposited above a regional breakup unconformity and represent a phase of relative tectonic quiescence. However, as demonstrated in this paper, older synrift units were accumulated in west Iberia prior to the latter extensional episodes that led to continental breakup. To simplify our analysis, we term this latter units as forming "prerift" successions, i.e., comprising strata accumulated prior to the last episode of rifting affecting the distinct basins referred to in this work as were, for instance, prerift strata drilled at DSDP Site 398 [Groupe Galice, 1979] and in ODP Leg 103 [Boillot et al., 1989].

[9] This paper utilizes the zonation proposed by Manatschal and Bernoulli [1998, 1999] for passive margins. It divides the west Iberian margin in (1) inner proximal margin, where onshore and continental shelf basins are located, (2) outer proximal margin, with multiple continental slope tilt blocks, and (3) distal margin, where highly extended crustal blocks and the ocean-continent transition are observed (Figure 2).

\section{Data and Methods}

[10] Regional (2-D) seismic reflection lines acquired on the southwest Iberian margin (Alentejo Basin) by TGSNOPEC and GSI Geophysics are used in this paper together with unpublished outcrop and well data from the Santiago do Cacém and shallow offshore areas (Figure 1b). These data are correlated with published information from the Lusitanian Basin [Wilson et al., 1989; Hiscott et al., 1990a; Alves et al., 2002, 2003b], the Porto Basin (C. Moita et al., Porto Basin: Seismic interpretation report, unpublished report, MILUPOBAS project, 1996), the Iberia Abyssal Plain [Wilson et al., 1996, 2001] and the Newfoundland-central eastern North American margin [Tankard and Welsink, 1987; Tankard et al., 1989; Withjack et al., 1998; Shipboard Scientific Party, 2004]. Seismic data interpretations were based on the methods of Mitchum et al. [1977] and Hubbard et al. [1985] for passive margins. The criteria of Driscoll et al. [1995] were used for the identification of key tectonic events affecting the North Atlantic region.

[11] The nomenclature adopted for each seismic unit was based on the seismic stratigraphic framework of Alves et al. [2002, 2003b, 2006] for the Lusitanian, proximal Alentejo and Peniche basins (Figure 1a). Relative dating of seismic units is based on published and unpublished information on the Lusitanian Basin [Atrops and Marques, 1986; Wilson et al., 1989], on the northwest Iberian margin [Groupe Galice, 1979; Boillot et al., 1989; Murillas et al., 1990; C. Moita et al., Porto Basin: Seismic interpretation report, unpublished report, MILUPOBAS project, 1996; Gabinete para a Pesquisa e Exploração de Petróleo (GPEP), Petroleum potential of Portugal, unpublished report, 1986], and on the Canadian/ Irish margins [Driscoll et al., 1995; Sinclair, 1995; 

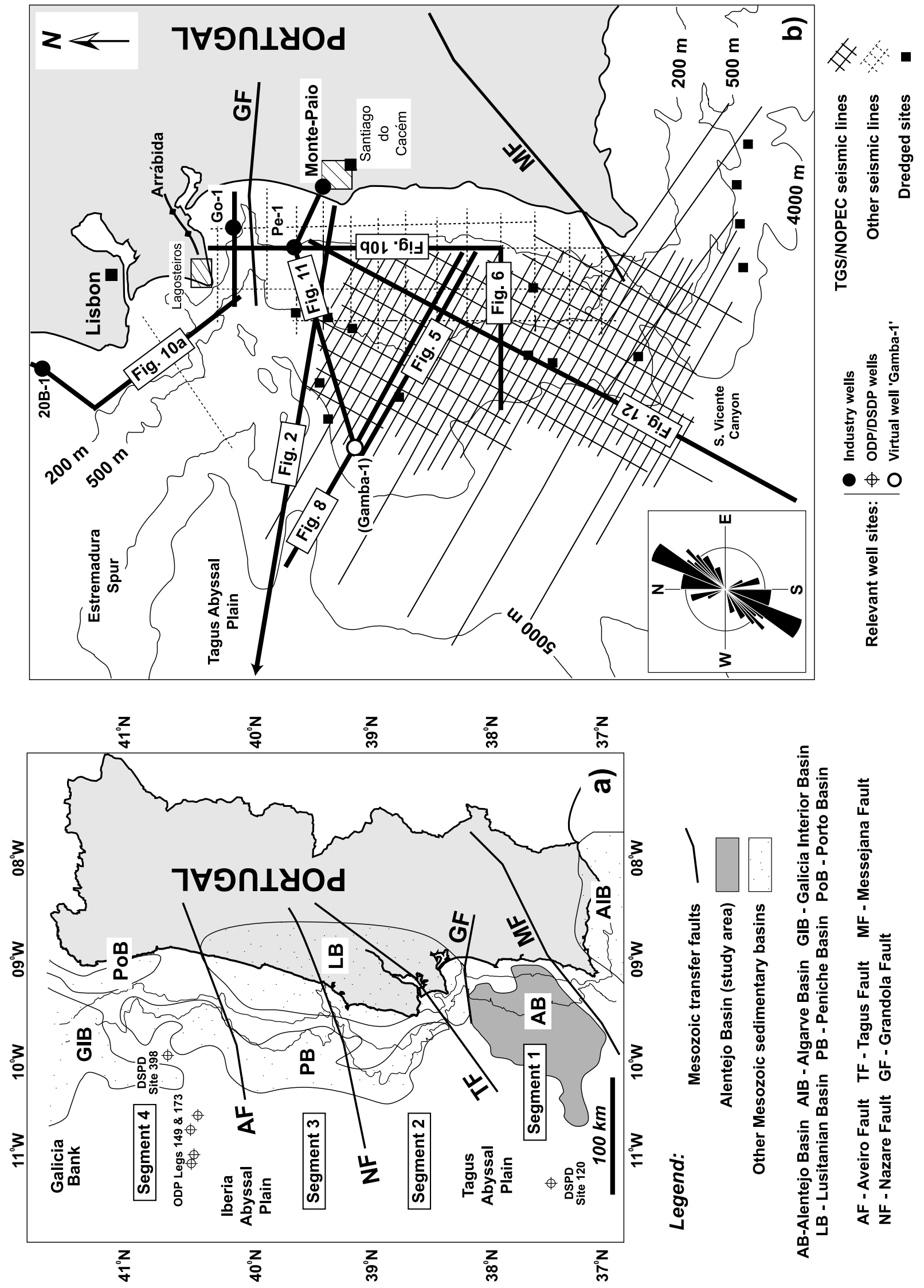

可

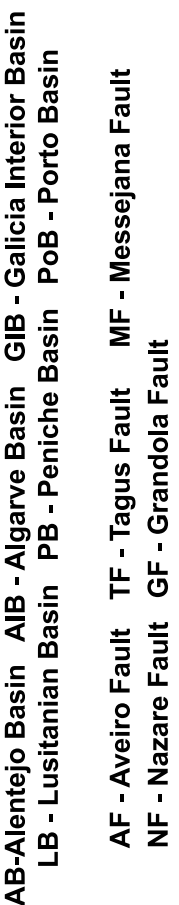


Williams et al., 1999; Shipboard Scientific Party, 2004]. Together with Industry well data (wells Pe-1 and Go-1), dredge data published by Mougenot et al. [1979] have been used locally to date some of the strata outcropping offshore Alentejo (Figure 1b).

\section{Geological Framework of Southwest Iberia}

\subsection{Structure and Physiography}

[12] West Iberia comprises a north striking passive margin with multiple Mesozoic basins (Figure 1a). In the study area, the continental shelf is limited by the $100-120 \mathrm{~m}$ isobaths and does not exceed $60 \mathrm{~km}$ in width. The continental slope is gentle and sparsely punctuated by seamounts, which generally comprise nonvolcanic rift-related horsts uplifted during latest Cretaceous-Cenozoic inversion [Mougenot et al., 1984; Alves et al., 2003a]. Inversion structures are locally responsible for destabilization of the continental slope [Terrinha et al., 2003].

[13] Major tectonic lineaments subdivide west Iberia into distinct crustal segments (segments 1 to 4, Figure 1a). Such lineaments relate to first-order transfer faults active during the Mesozoic rifting phases [Groupe Galice, 1979] and comprise, in southwest Iberia, the offshore prolongations of the Messejana and Grândola faults (Figure 1). The Grândola Fault separates segment 2 (Estremadura Spur) and the offshore prolongation of the Lusitanian Basin from the study area. The offshore prolongation of the Messejana Fault separates the study area (segment 1) from the Algarve Basin (Figure 1). North of the Nazaré Fault two other segments, segments 3 and 4, are recognized [Alves et al., 2006].

\subsection{Mesozoic Rifting}

[14] Outcrop data reveal three major Mesozoic extensional episodes: Triassic (rift 1), Sinemurian-early Pliensbachian (rift 2) and late Oxfordian (rift 3), the latter marking the principal episode of subsidence in the Lusitanian Basin [Leinfelder and Wilson, 1998; Stapel et al., 1996; Alves et al., 2002] (Figures 1a and 3). Late Oxfordian-early Kimmeridgian extension in the latter basin has been considered the precursor of ocean spreading in the Tagus Abyssal Plain [Wilson et al., 1989] with recent models indicating a Valanginian age for this latter event [Pinheiro et al., 1992]. Alternatively, the oldest magnetic anomaly in the Tagus Abyssal Plain may be M20 [Srivastava et al., 2000], which may indicate a latest Jurassic (late Tithonian, $147 \mathrm{Ma}$ ) age for continental breakup in southwest Iberia (Figure 3).

[15] In the Santiago do Cacém area (onshore segment 1, Figure 1b), rifts 1,2 , and 3 have been documented and precede a latest Kimmeridgian relative sea level fall [Ramalho, 1971; Inverno et al., 1993]. Consequently, Tithonian strata are not represented at outcrop in southwest
Iberia. They comprise shallow marine to transitional carbonate successions at Lagosteiros and well Pe-1, equivalent to prograding continental units deposited in the eastern Arrábida region (GPEP, unpublished report, 1986) (Figure 1b). An equivalent latest Kimmeridgian sea level fall is also recorded in the central part of the Lusitanian Basin but siliciclastic sedimentation predominated in the basin until the earliest Cretaceous [Ravnås et al., 1997].

[16] A fourth extensional episode (rift 4) of Early Cretaceous age occurred northwest of the Lusitanian Basin in association with northward migration of the principal rift axis toward the Iberia Abyssal Plain (Figure 3). At the time, a new extensional trough was generated in response to a propagating rift that was diachronous and successively younger toward the north [Whitmarsh and Miles, 1995; Whitmarsh et al., 1996]. In this context, the Nazaré Fault has been interpreted as a major tectonic feature, separating an area of pre-Barremian seafloor spreading (Tagus Abyssal Plain) from a northern region of continental rifting extending to the Charlie Gibbs Fracture Zone [Driscoll et al., 1995] (Figure 3).

[17] Recent models comparing the northwest Iberian (Galicia) and Adria margins reveal the existence of three main evolution stages on nonvolcanic passive margins: (1) an early rifting stage, in which widespread sedimentation occurs within a sag basin during the early phases of continental rifting, (2) an advanced rifting stage, in which structural segmentation of the margin occurs and rift climax units are deposited in evolving subbasins, and (3) an advanced rifting and transition to seafloor spreading stage, occurring in the distal margin, characterized by the formation of highly rotated listric blocks bounded by low-angle (deep) detachments faults and by the relative absence of rift climax units in evolving subbasins [Manatschal and Bernoulli, 1998, 1999; Wilson et al., 2001]. In parallel, Michon and Merle [2003] have compared, and modeled, lithospheric extension on different passive margins, concluding that there is a shift in the principal locus of extension from interior rift basins to the deeper margin during the last stages of continental rifting, i.e., during the advanced rifting stage of Manatschal and Bernoulli [1998, 1999]. In both evolution models, a period of $\sim 25 \mathrm{Ma}$ of (synrift) stretching commonly precedes continental breakup [Whitmarsh et al., 2001].

[18] The previous models agree with data from northwest Iberia, which led several authors to propose a pure shear extensional model for an initial boudinage stage of lithospheric extension, followed by simple shear in a later detachment fault stage [Boillot and Froitzheim, 2001]. As expected on a lower plate margin, the presence of a deep west dipping crustal detachment (S reflector) was recognized as accommodating the extension and relative rotation of crustal blocks, particularly toward distal highly extended

Figure 1. (a) Map of the western Iberian continental margin showing the Alentejo Basin in relation to major transfer faults and adjacent shallow offshore basins. Note the location of the four distinct crustal segments comprising the west Iberian margin. (b) Map of the study area depicting the interpreted seismic grid plus the location of offshore Industry wells and dredged sites. The rose diagram shows the main structural trends in the Alentejo Basin. 


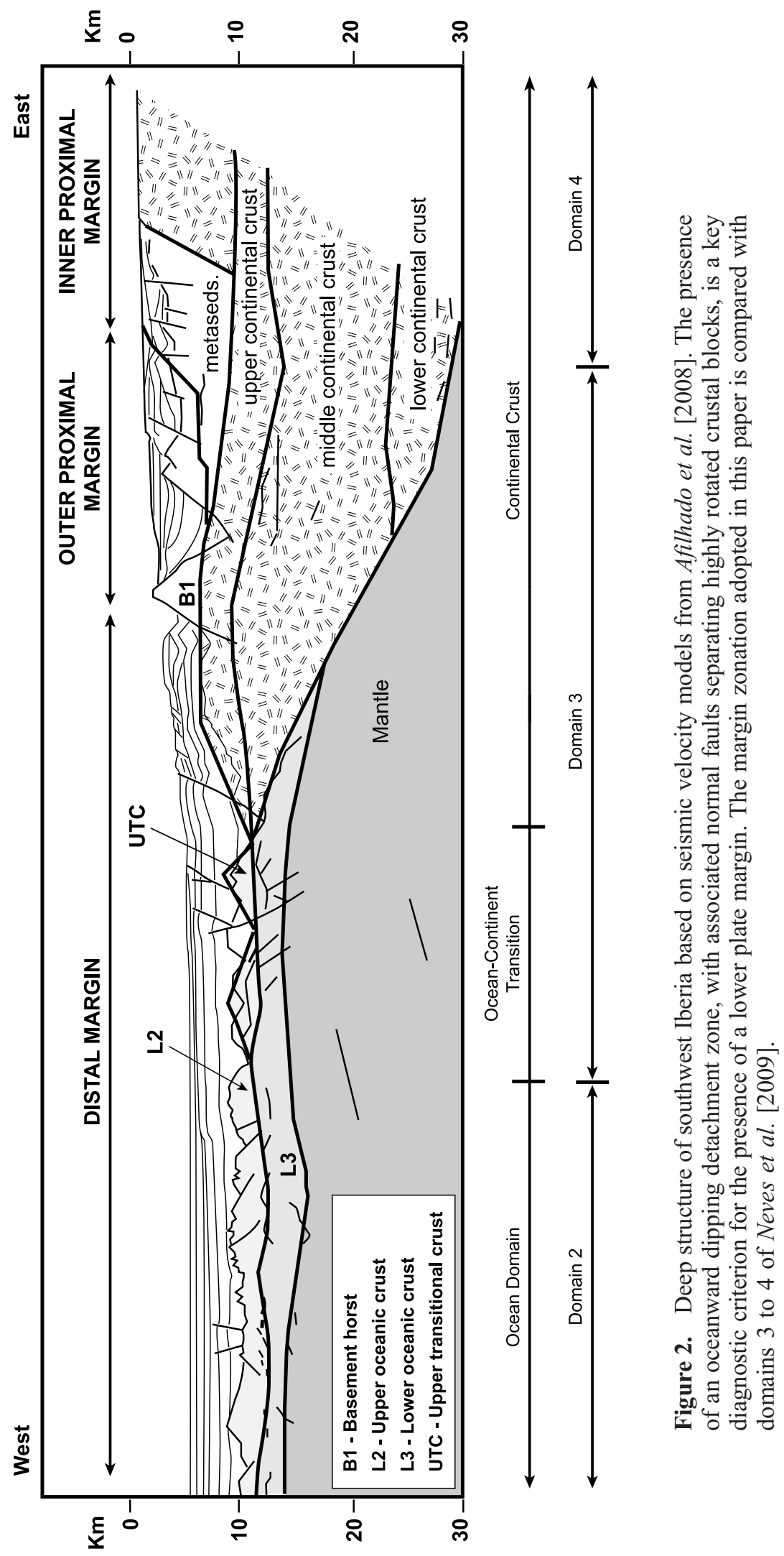




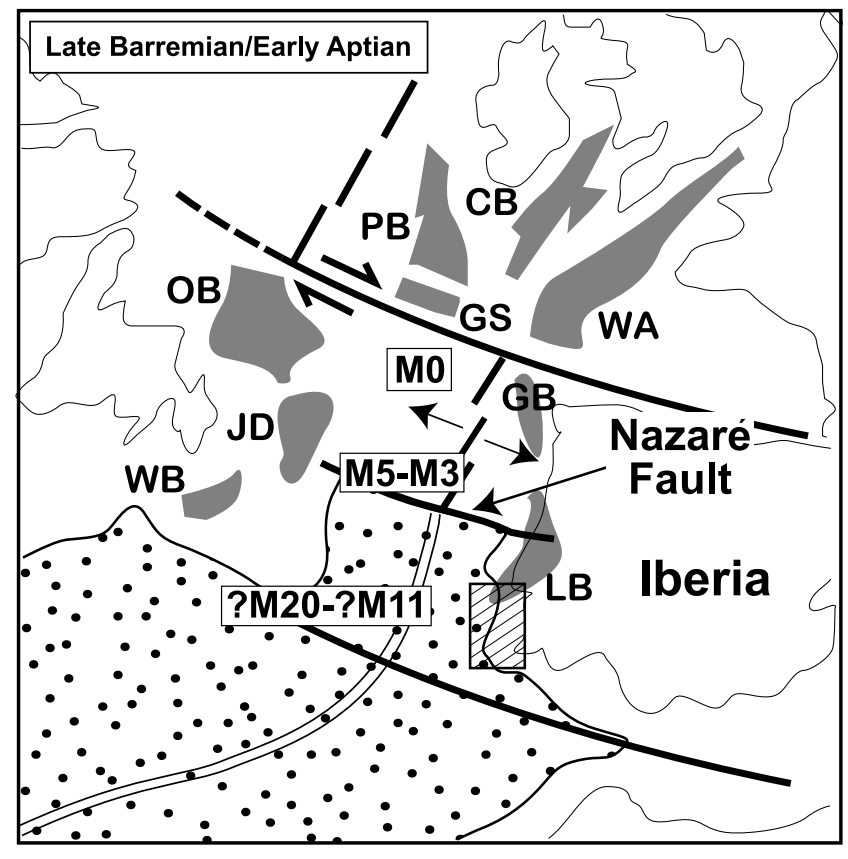

Legend:

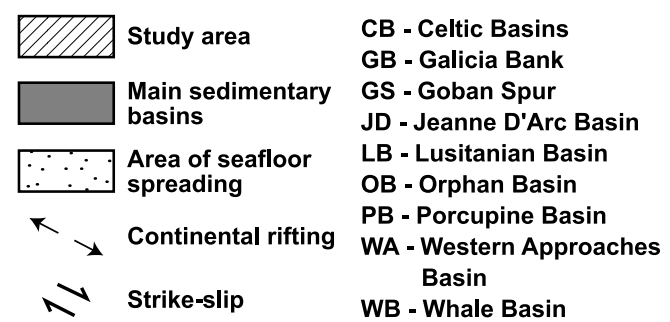

Age of magnetic anomalies:

M20-M11 - Late Tithonian to Valanginian (147-134 Ma)

M5 to M3 - Early Barremian to Late Berramian (128-126 Ma)

M0 - Early Aptian (121 Ma)

Figure 3. Reconstruction of the North Atlantic during the late Barremian/early Aptian showing the relative location of sedimentary basins offshore Newfoundland and west Iberia, together with first magnetic anomalies recorded between the two margins. Modified from Driscoll et al. [1995] with permission from Geological Society. Absolute dates based on the time scale of Gradstein et al. [1995].

regions [Reston et al., 1995]. A similar extensional model is proposed for southwest Iberia [Afilhado et al., 2008].

\subsection{Late Cretaceous-Cenozoic Evolution}

[19] After rift 4, continued northward migration of seafloor spreading drove ocean opening in the Bay of Biscay (Late Cretaceous) and triggered counterclockwise and southeast motion of Iberia [Thinon et al., 2002; Pinheiro et al., 1996]. Continental collision with Eurasian (Eocene) and African crust (Miocene), caused basin inversion on the inner proximal margin of west Iberia and led to the exhumation of vast synrift successions in central Spain (Iberian Ranges) and Portugal (Lusitanian and Algarve basins). Onshore, the degree and style of basin inversion was dependent on the relative thickness of latest TriassicHettangian evaporites at depth [Ribeiro et al., 1990] and on the distance to the main axes of collision [Roca et al., 2006]. Salt-poor regions are characterized by the reactivation, and subsequent propagation within the post-Hettangian overburden, of deep-rooted basement faults. Diapir growth, salt extrusion and reactivation of salt anticlines occurred in evaporite-rich areas [Canérot et al., 1995; Rasmussen et al., 1998].

[20] In southwest Iberia, a series of structural domains with distinct responses to Cenozoic compression have been recognized by Neves et al. [2009]. According to these authors, the study area is shown as a region of significant inversion thrusting (domain 3 ), with relatively minor extensional and shortening structures (domain 4) close to the coastline (Figure 2).

\section{Seismic Stratigraphy}

[21] The regional seismic stratigraphy of the southwest Iberian margin is shown in Figure 4 and Table 1. Main seismic megasequences, sequences and packages are also described by Mauffret et al. [1989a, 1989b] and Alves et al. [2003a]. In summary, seven megasequences can be identified in the study area (Table 1).

\section{1. $\mathbf{T} / \mathbf{J} 2$ Megasequence: Triassic to Callovian}

[22] The T/J2 Megasequence comprises the basal seismic-stratigraphic unit in southwest Iberia (Figures 5 and 6). The megasequence shows chaotic to subparallel internal reflections with moderate amplitude. On the outer proximal margin, it underlies Late Jurassic-earliest Cretaceous synrift strata deposited on tilt blocks (Figure 5). Moderate thickening of strata is observed close to basin-bounding faults and in parts of the inner proximal margin. The unit can reach more than $1.7 \mathrm{~s}$ two-way traveltime (twtt) in the outer proximal margin (Figure 5). The T/J2 Megasequence correlates with Triassic to Middle Jurassic strata in Santiago do Cacém. Here, red continental units occur at the base of the succession, followed by a Sinemurian-Toarcian volcanosedimentary complex, dolomites and limestones of Sinemurian to Callovian age [Inverno et al., 1993] (Figure 4).

\subsection{J3 Megasequence: Early Oxfordian-Kimmeridgian}

[23] The J3 Megasequence is preserved in fault-bounded grabens and half grabens on the outer proximal margin (Figure 5). The unit comprises prerift strata in the Peniche Basin [Alves et al., 2006] but shows rift-related tectonics systems tracts in the sense of Prosser [1993] in the study area (Figure 5). Its thickness reaches $1.5 \mathrm{~s} \mathrm{twtt}$ on the outer proximal margin, but is substantially thinner toward the coastline [Alves et al., 2003a]. Marked onlap onto adjacent structural highs is observed within half graben subbasins. Onshore, the J3 Megasequence comprises limestones, marls and conglomerates in Santiago do Cacém [Inverno et al., 1993]. 


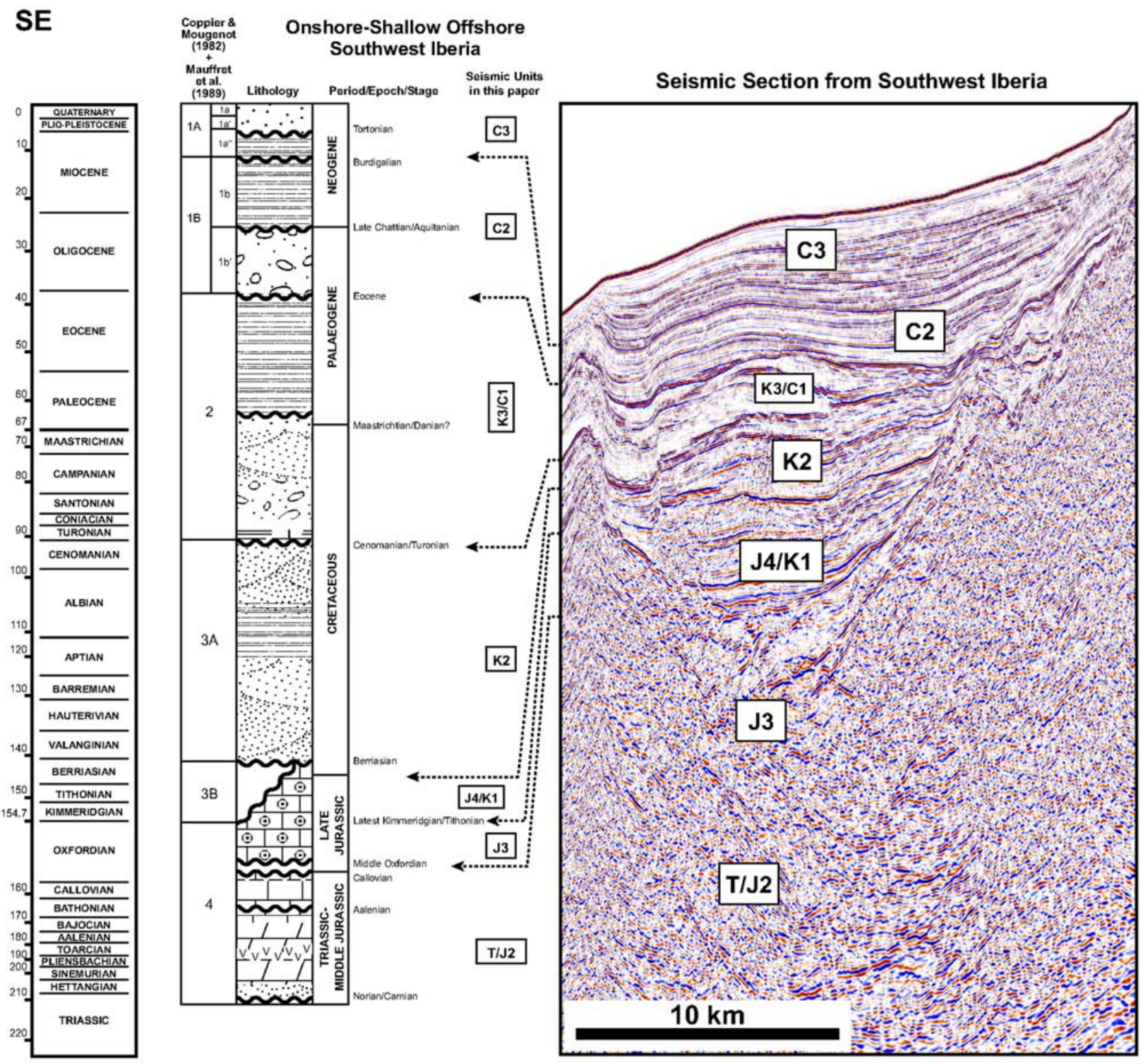

Lithology key for southwest Iberia and Lusitanian Basin

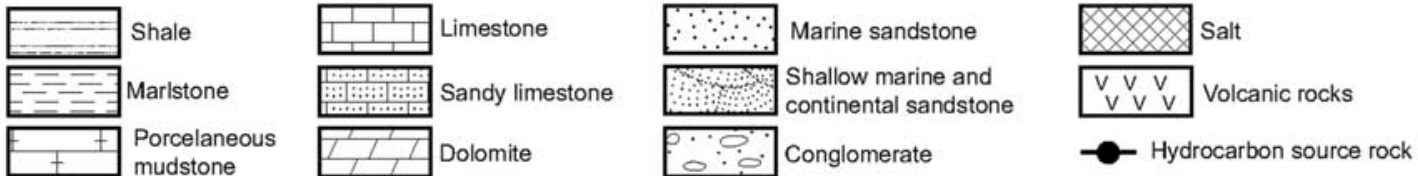

Figure 4. Correlation panel among the interpreted seismic-stratigraphic units and well data from the Lusitanian Basin [Alves et al., 2002], DSDP Site 398 [Groupe Galice, 1979; Réhault and Mauffret, 1979]. Seismic stratigraphic units in the Alentejo and Lisbon inner proximal margins, as interpreted by Coppier and Mougenot [1982] and Mauffret et al. [1989a, 1989b], and Peniche Basin [Alves et al., 2006] are correlated with seismic-stratigraphic units. See Figure 5 for the detailed location of the seismic section. 


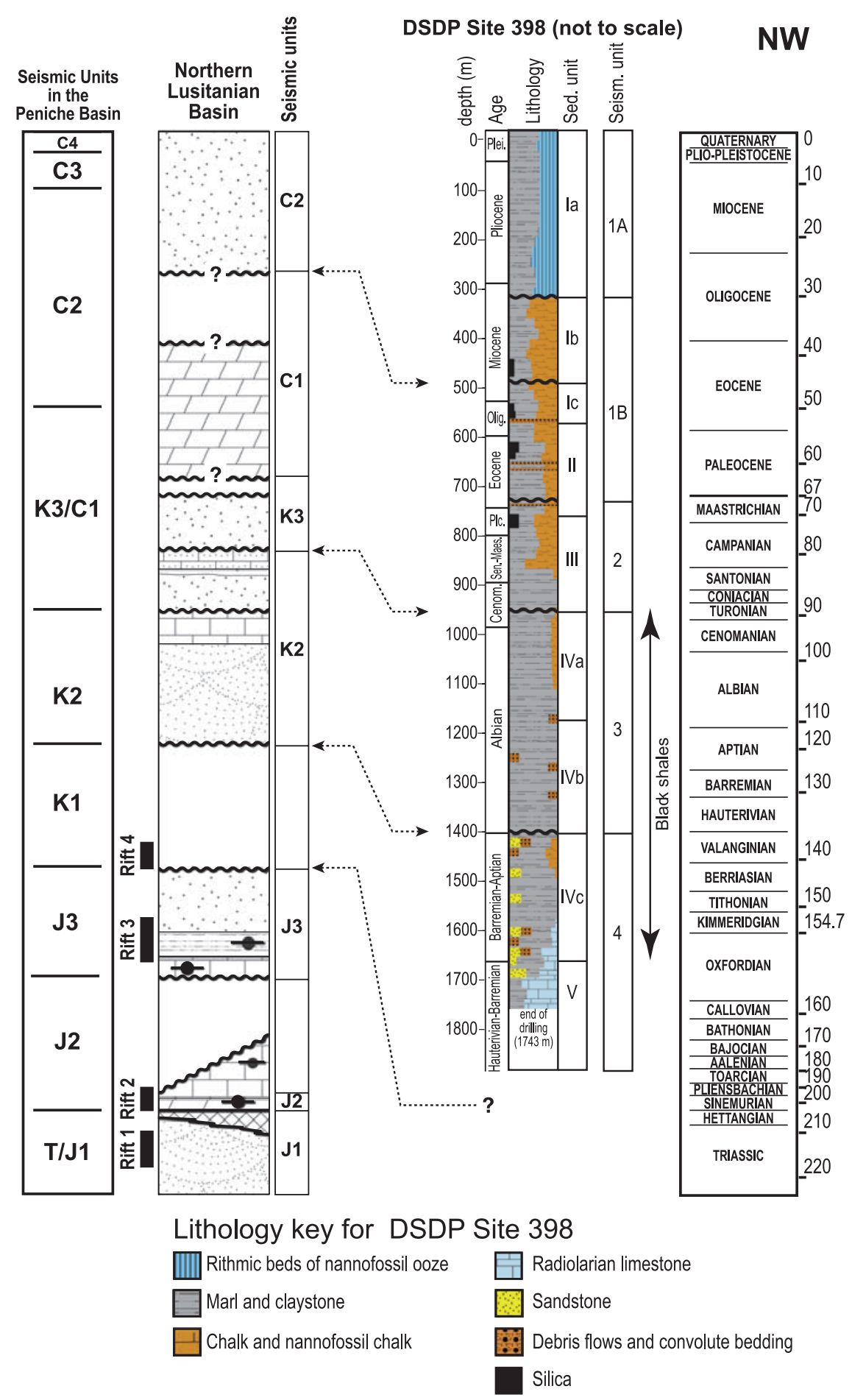

Figure 4. (continued)

\subsection{J4/K1 Megasequence: Latest Kimmeridgian-Late} Berriasian/Valanginian?

[24] The J4/K1 Megasequence comprises a transparent to low-amplitude unit (Figure 5). Baselap terminations onto unit $\mathrm{J} 3$ and adjacent structural highs on the outer proximal margin are observed. Megasequence $\mathrm{J} 4 / \mathrm{K} 1$ is up to $1.1 \mathrm{~s}$ twtt thick and characterized by subhorizontal reflections (Figure 5). Profiles across the main subbasins reveal that the unit is preserved in fault-bounded grabens and half grabens. Locally, strata thicken toward basin-bounding normal faults, particularly toward the base. On the inner proximal margin, correlative units in well $\mathrm{Pe}-1$ are shown as high-amplitude 
Table 1. Summary of the Principal Features of the Seismostratigraphic Units in the Alentejo Basin

\begin{tabular}{|c|c|c|c|c|c|}
\hline Seismic Units & Age of base & $\begin{array}{l}\text { TWTT } \\
\text { Thickness } \\
\text { (ms) }\end{array}$ & $\begin{array}{c}\text { Internal Character, } \\
\text { Geometry and Terminations }\end{array}$ & Probable Lithology ${ }^{a}$ & $\begin{array}{l}\text { Seismic } \\
\text { Units }^{b}\end{array}$ \\
\hline $\mathrm{C} 3$ & early/middle Miocene & $0-400$ & $\begin{array}{l}\text { Low- to high-amplitude subparallel } \\
\text { reflections. Wavy toward the upper } \\
\text { continental slope. Baselap }\end{array}$ & $\begin{array}{l}\text { Interbedded sand- to clay-rich } \\
\text { turbidites, hemipelagites and pelagites. }\end{array}$ & $1 \mathrm{~A}$ \\
\hline $\mathrm{C} 2$ & late Eocene & $0-400$ & $\begin{array}{l}\text { Low- to moderate-amplitude internal } \\
\text { reflections, subparallel to wavy, locally } \\
\text { transparent. Comprises the lower } \\
\text { part of thick strata draping the lower } \\
\text { continental slope. Baselap. }\end{array}$ & $\begin{array}{l}\text { Interbedded sand- to clay-rich countourites, } \\
\text { turbidites, hemipelagites and pelagites. }\end{array}$ & $1 \mathrm{~B}$ \\
\hline $\mathrm{K} 3-\mathrm{C} 1$ & late Cenomanian/Turonian & $0-500$ & $\begin{array}{l}\text { Low- to moderate-amplitude internal } \\
\text { reflections, chaotic to subparallel. } \\
\text { Wedge-shaped prograding unit } \\
\text { thickening to the eastwest. Downlap. }\end{array}$ & $\begin{array}{l}\text { Mass transport complexes, interbedded } \\
\text { with turbidite and hemipelagic material. }\end{array}$ & 2 \\
\hline $\mathrm{K} 2$ & late Valanginian & $0-700$ & $\begin{array}{l}\text { Low- to moderate-amplitude westerly } \\
\text { tilted clinoforms, mounded at places. } \\
\text { Drapes horst structures. Prograding } \\
\text { reflections on upper continental slope. }\end{array}$ & $\begin{array}{l}\text { Local mass transport complexes and turbidites. } \\
\text { Essentially siliciclastic material deposited on } \\
\text { a structurally bounded continental slope. }\end{array}$ & $3 \mathrm{~A}$ \\
\hline $\mathrm{J} 4 / \mathrm{K} 1$ & late Kimmeridgian & $0-1100$ & $\begin{array}{l}\text { Low- to moderate-amplitude internal } \\
\text { reflections. Localized growth onto } \\
\text { basin margin structures. Fills half } \\
\text { graben/graben blocks close to the } \\
\text { continental slope. Onlap onto its base. }\end{array}$ & $\begin{array}{l}\text { Postrift clayey and sandy turbidites. Higher } \\
\text { sand rates related to active fault structures } \\
\text { and to submarine canyons. Carbonate levels } \\
\text { may be present in the association. }\end{array}$ & $3 \mathrm{~B}$ \\
\hline $\mathrm{J} 3$ & early Oxfordian & $0-1500$ & $\begin{array}{l}\text { Moderate- to high-amplitude parallel } \\
\text { reflections showing localized growth } \\
\text { onto basin margin structures. It } \\
\text { comprises synrift units in the Alentejo } \\
\text { Basin. Folded strata on the continental } \\
\text { shelf. Baselap is visible. }\end{array}$ & $\begin{array}{l}\text { Synrift siliciclastic (fluvial/deltaic?) and } \\
\text { carbonate material on the continental } \\
\text { slope. Marine siliciclastics (turbidites) } \\
\text { in the deeper areas of margin. } \\
\text { Carbonate successions on the } \\
\text { continental shelf and onshore. }\end{array}$ & 4 \\
\hline $\mathrm{T}-\mathrm{J} 2$ & Triassic? & $0-1700$ & $\begin{array}{l}\text { Chaotic to parallel internal reflections. } \\
\text { Wedge- to lensoid-shaped unit, locally } \\
\text { tilted. Occurs at the base of half } \\
\text { graben/graben blocks. Baselap is visible. }\end{array}$ & $\begin{array}{l}\text { Continental to shallow marine siliciclastics } \\
\text { and evaporites. }\end{array}$ & 4 \\
\hline
\end{tabular}

${ }^{\mathrm{a}}$ From Mougenot et al. [1984] and Alves et al. [2003a].

${ }^{\mathrm{b}}$ From Mauffret et al. [1989b].

strata cut by normal faults (Figure 6). Uppermost Kimmeridgian-Valanginian strata are absent at outcrop (Santiago do Cacém) but comprise shallow marine carbonates in well Pe-1 [Inverno et al., 1993].

\subsection{K2 Megasequence: Late Valanginian-Cenomanian}

[25] The K2 Megasequence is characterized by low- to moderate-amplitude, continuous, internal reflections (Figure 5). Baselap onto its upper and lower boundaries is observed. On the outer proximal margin, the unit drapes riftrelated structural highs and synrift strata. Prograding reflections are also observed (Figure 6). The K2 Megasequence reaches $0.7 \mathrm{~s}$ twtt in thickness. Well Pe-1 drilled continental shales, sands and conglomerates in $\mathrm{K} 2$.

\subsection{K3/C1 Megasequence: Late Cenomanian/Turonian- Eocene}

[26] The K3/C1 Megasequence is represented by transparent to low-amplitude internal reflections reaching a thickness of $0.5 \mathrm{~s}$ twtt. In most of the study area, $\mathrm{K} 3 / \mathrm{C} 1$ is mostly chaotic and comprises sigmoidal reflections with marked downlap west of the shelf edge (Figure 6). The K3/ C1 Megasequence does not occur onshore but has been comprehensively dredged [Mougenot et al., 1979]. Latest Cretaceous to Eocene marine microfauna have been collected toward the southern part of the study area.

\subsection{C2 Megasequence: Late Eocene to Early Miocene}

[27] The C2 Megasequence comprises subparallel, continuous reflections with low- to high-amplitude internal reflections (Figure 5). On the inner proximal margin, the unit shows high-amplitude reflections, gentle folding and minor variations in thickness. An erosional boundary marks its upper boundary. Onlap is observed onto its lower boundary. Coppier and Mougenot [1982] dated C2 as upper Eocene-lower Miocene using dredged rock samples.

\subsection{C3 Megasequence: Middle Miocene to Holocene}

[28] The C3 Megasequence comprises a thick succession of subhorizontal strata draping the outer proximal margin. It is marked by low- to high-amplitude continuous reflections alternating with transparent intervals (Figure 5). Onlap occurs at the base of $\mathrm{C} 3$. Borehole data (Pe-1 well) indicate a middle Miocene to Holocene age for C3. Its thickness ranges between less than $0.1 \mathrm{~s}$ twtt on the continental shelf to more than $1.5 \mathrm{~s}$ twtt on outer proximal margin (Figure 6). 

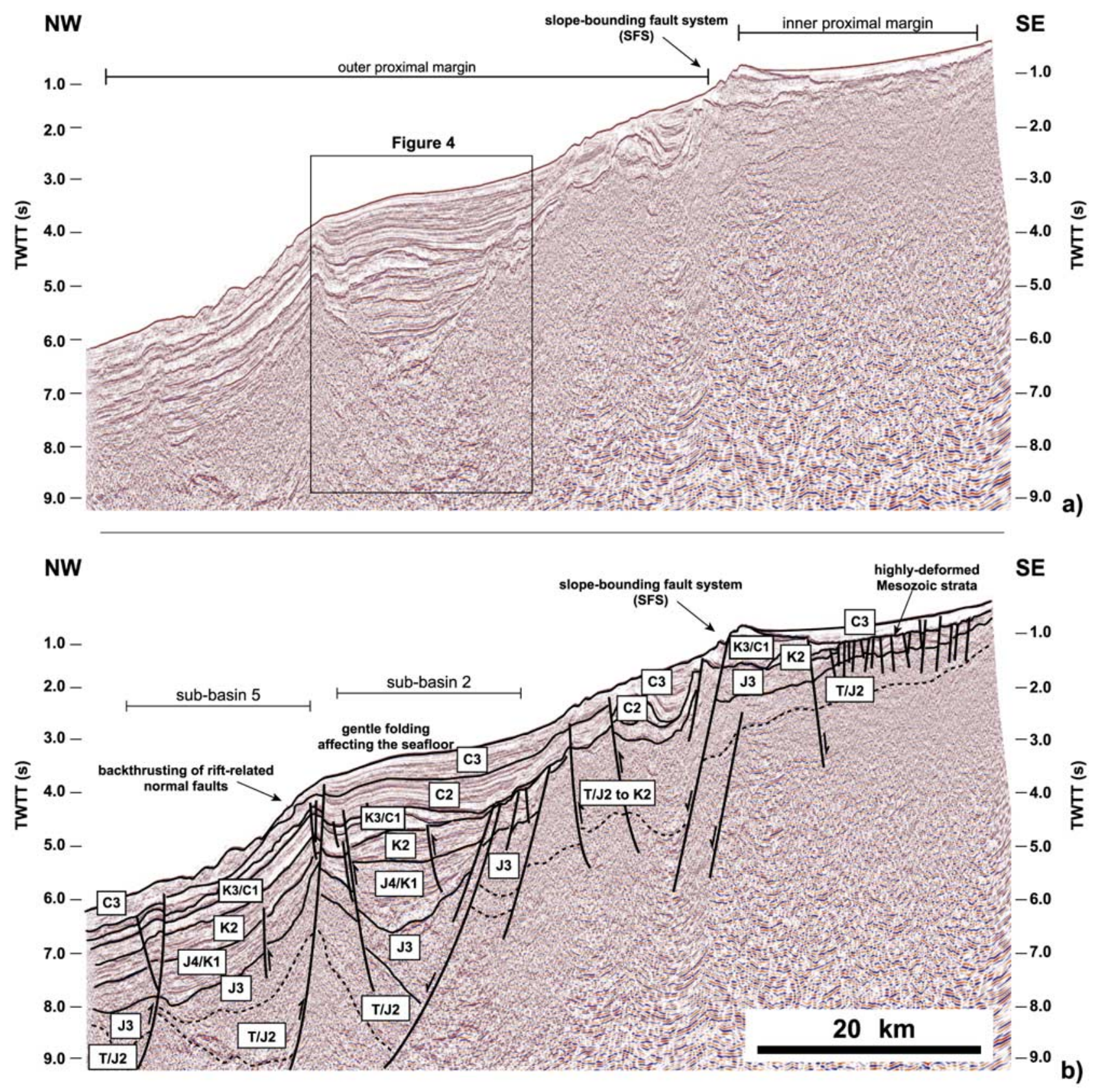

Figure 5. (a) Seismic section and (b) corresponding interpretation of a NW-SE seismic profile crossing the continental slope in southwest Iberia (see Figure $1 \mathrm{~b}$ for location). Jurassic half grabens are depicted in the section. Note the dissection of the margin by a series of normal faults and the contrasting structural style of the margin east of the SFS. Seismic line courtesy of TGS/NOPEC Geophysical Company.

C3 dredge samples include hemipelagic muds, sands and sparse carbonates [Mougenot et al., 1979].

\section{Structure of the Southwest Iberian Margin}

[29] Figure 5 depicts the structure of the southwest Iberian margin. On the inner proximal margin, Mesozoic units are relatively thin (less than $1.5 \mathrm{~s}$ twtt) and are deformed by pervasive sets of normal faults. High- amplitude folds and pervasive faulting of Mesozoic strata are also observed. In contrast, well-developed tilt blocks occur on the outer proximal margin, where they are draped by thick Cretaceous and Cenozoic strata. A major fault system separates tilt blocks on the outer continental margin from the inner proximal margin. This slope-bounding fault system (SFS) delimits the principal locus of Mesozoic subsidence to a $150-\mathrm{km}$-wide region west of $9^{\circ} 30 \mathrm{~W}$, oriented along the margin (Figure 5). 

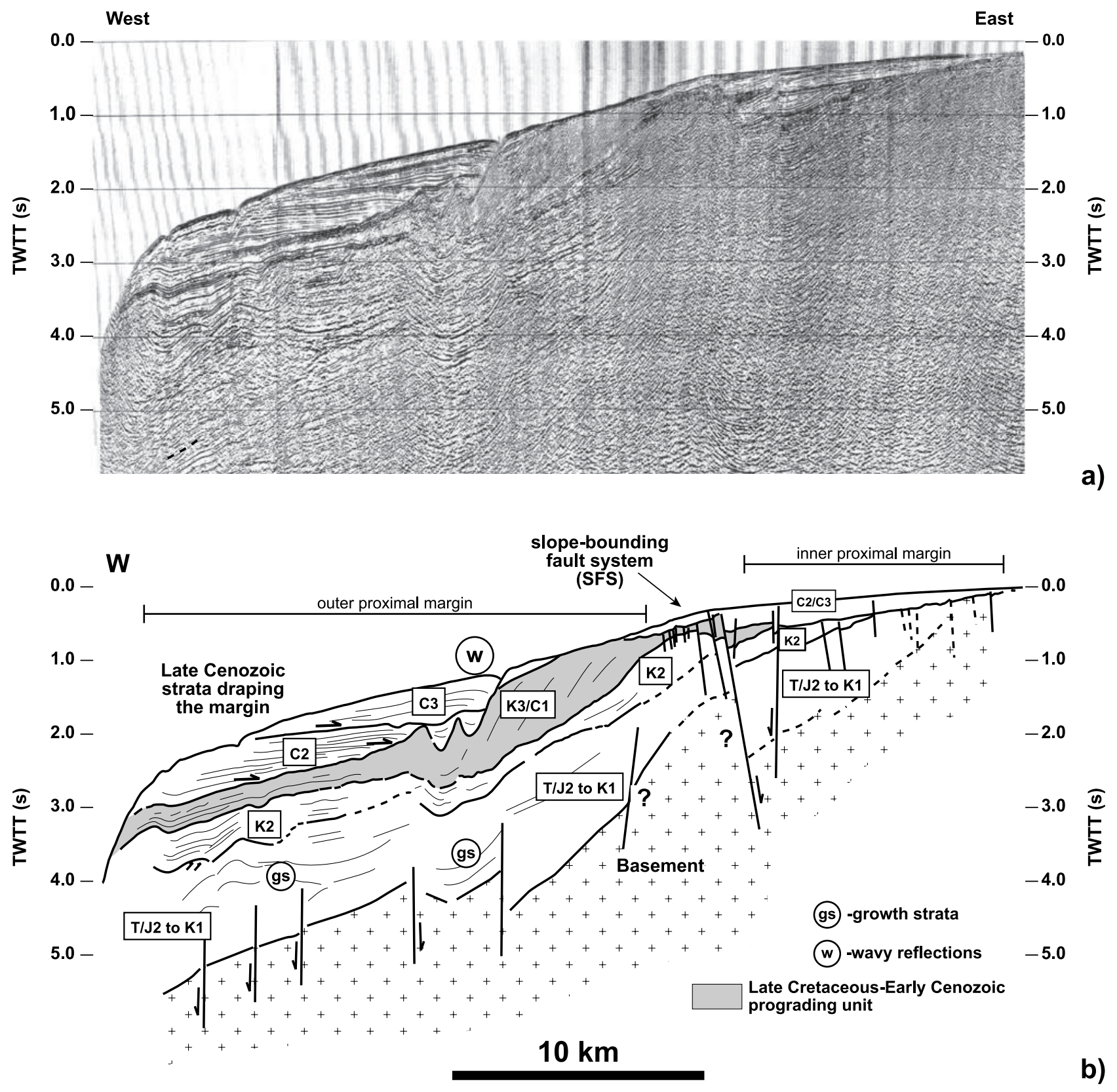

Figure 6. (a) Seismic section and (b) corresponding interpretation of an E-W striking seismic line located on the SFS (see Figure 1b for location). Note the progradation of Late Cretaceous-early Cenozoic strata $(\mathrm{K} 2$ and $\mathrm{K} 3 / \mathrm{C} 1)$ over the SFS. Rift-related strata are relatively thin east of this structural boundary.

[30] Isopach data highlight the existence of six main subbasins on the outer proximal margin (Figure 7). The isopach maps highlight the location of Late Jurassic depocenters offshore Alentejo but do not account for the existence of up to $1.7 \mathrm{~s}$ twtt of Triassic-Middle Jurassic strata in underlying prerift successions. Velocity values for each of the interpreted megasequences were based on information from well Pe-1.

[31] In the study area, continental slope basins can comprise more than $9.0 \mathrm{~km}(\sim 5.0 \mathrm{~ms}$ twtt $)$ of strata including the Triassic-Middle Jurassic successions at the base of rotated tilt blocks (Figures 5 and 8). This value is similar to that recorded in the deeper parts of the Peniche Basin [Alves et al., 2006]. However, developed salt diapirs and associated minibasins as those observed offshore Peniche have not been recognized in the study area. The absence of salt structures also contrasts with the deep offshore area east of the Jeanne D'Arc basin [Jansa et al., 1980], with the Algarve Basin [Terrinha, 1998] and with parts of the Lusitanian Basin [Alves et al., 2003b] but 


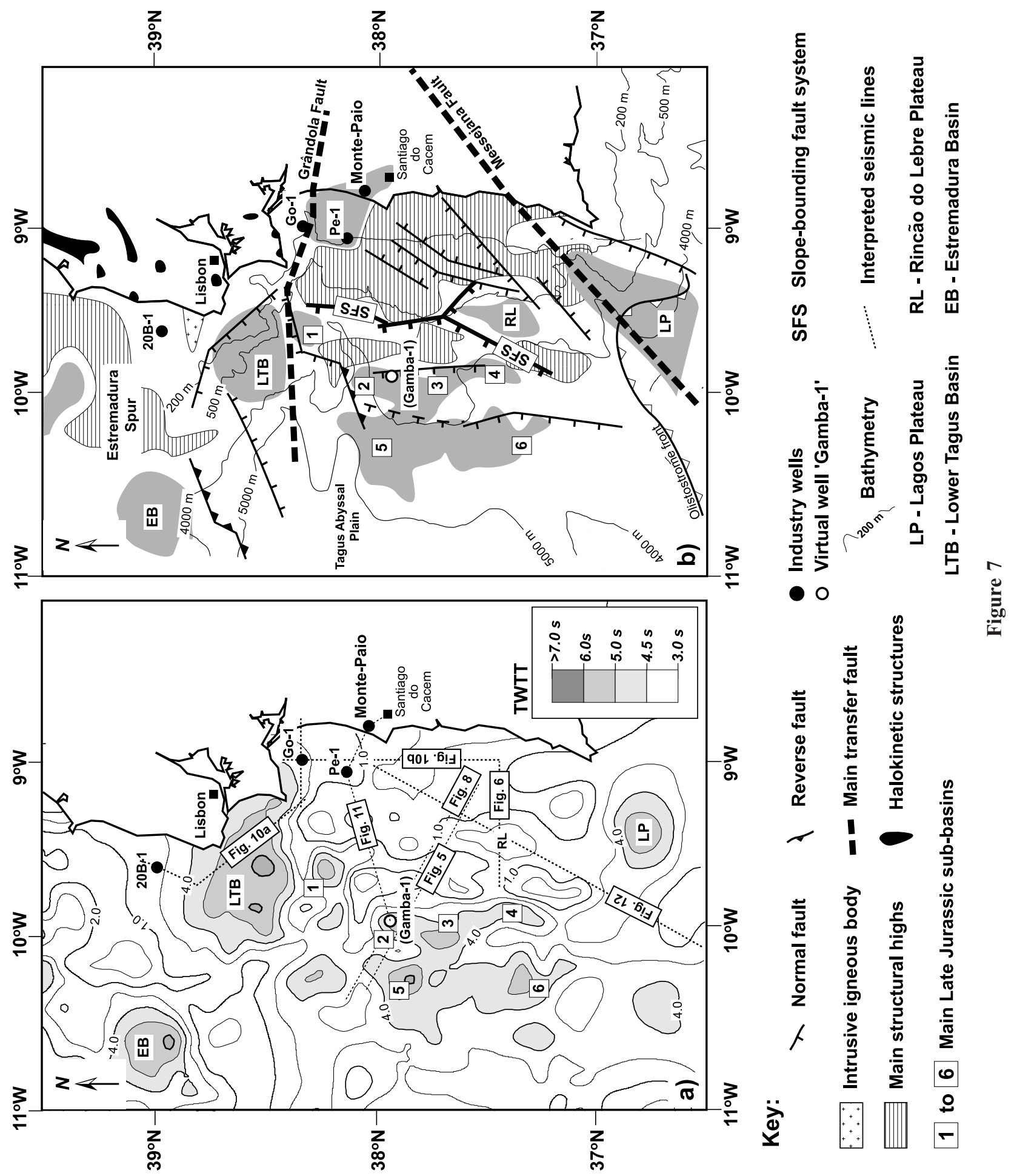


correlates positively with outcrop information from the Santiago do Cacém area where Triassic-Hettangian evaporites are absent [Inverno et al., 1993] (Figures 1 and 4).

[32] The isochron map in Figure 9a depicts the twtt structure (in time) of Triassic-Jurassic units on the inner proximal margin, highlighting at the same time the existence of thick synrift strata west of the SFS. TriassicJurassic strata are less than $0.9 \mathrm{~s}$ twtt east of the SFS, reaching more than $2.0 \mathrm{~s}$ on the outer proximal margin (Figure 8). Three distinct sets of normal faults are observed, with the dominant set striking north-south and secondary sets striking north-northwest and north-northeast. Major faults west of the SFS are typically 70 to $90 \mathrm{~km}$ long, while faults in the inner proximal margin are 10 to $30 \mathrm{~km}$ long (Figure 9a). In addition, a large fault, herein called the Sines Fault, separates two distinct sectors on the inner proximal margin: (1) a northern sector with northwest trending subbasins and associated structures and (2) a southern sector with northeast trending subbasins (Figure 9a).

[33] Principal faults in the inner proximal margin are better depicted in Figure 9b, which shows the Base Cenozoic structure. North of the Sines Fault, Mesozoic and early Cenozoic strata dip to the northwest, while the southern sector of the study area shows equivalent strata dipping to the southwest (Figure 9b). Overall, the structure of the study area is similar to that of the Peniche Basin [e.g., Alves et al., 2006] with a segmented outer proximal margin formed of tilt blocks controlled by west dipping normal faults. Inner proximal basins are separated from their counterparts on the outer proximal margin by a shelf edge structural high, capped by postrift strata. Significant erosion and/or exhumation of rift-related and basement strata is observed east of the SFS. In contrast to the inner proximal margin, Mesozoic half graben/graben basins west of the SFS are covered by up to $2.5 \mathrm{~s}$ twtt of Cenozoic strata (Figures $7 \mathrm{~b}$ and 8 ).

\section{Onset of a Passive Margin Configuration}

[34] In southwest Iberia, the most significant event occurring after Tithonian-early Cretaceous continental breakup comprises the development of a prograding slope system in the Late Cretaceous-early Cenozoic. In detail, Figure 6 shows marked clinoform reflections in $\mathrm{K} 2$ and $\mathrm{K} 3 / \mathrm{E} 1$. Originally interpreted as a thick olistostrome unit of probable late Cretaceous age [Baldy, 1977], the K3/E1 Megasequence is reinterpreted in this paper as comprising southwesterly prograding slope deposits. In fact, sediment progradation in the Late Cretaceous and early Cenozoic is striking in the southern sector and contrasts with a simpler subhorizontal draping observed in the northern sector on the outer proximal margin (Figures 5 and 8). This period of slope progradation is shown on seismic data to be associated with regional tilting and thermal uplift in the central proximal part of the margin $\left(38^{\circ} \mathrm{N}\right)$, most likely in association with the intrusion of the Sines igneous complex, an intrusive batholith of intermediate to basic composition emplaced at the end of the Cretaceous in the Sines region (Campanian-Maastrichtian [Inverno et al., 1993]) (Figure 9). In fact, the Sines Fault roughly coincides with the axis of a regional northeast-southwest flexure on the inner proximal margin (Figure 9). The interpreted seismic data also shows that the mapped SFS constituted not only the boundary to slope progradation during the Late Mesozoic-Paleogene, extending into K2 toward the south, but also delimited late Cenozoic subhorizontal strata on the outer proximal margin (Figures 6 and 8).

[35] In order to illustrate the evolution of the southwest Iberian margin during its postrift stage, interpreted profiles and relevant stratigraphic data are shown in Figures 10 and 11. In summary, the interpreted data confirms that three main regions of subsidence existed on the proximal margin of southwest Iberia after Late Jurassic-earliest Cretaceous continental rifting, as indicated by their tectonosedimentary evolutions: (1) an inner proximal margin where postrift strata are relatively thin, limited deposition occurred after the Late Jurassic and no major depocenters occurred during the Cenozoic; (2) an outer proximal margin where thick $(>2.0 \mathrm{~s}$ twtt) postrift units are observed; and (3) a distal margin where most of the basin inversion occurred. In this setting, the SFS shows distinct styles of tectonic reactivation during the Cenozoic compressional episodes (Figures 8, 10, and 11).

\section{Basin Inversion}

[36] The absence of halokinetic structures, reflecting the existence of thin early Mesozoic evaporite successions at depth, was a key factor in the structural evolution of southwest Iberia when compared with the Peniche, Lusitanian and Algarve basins [e.g., Terrinha, 1998; Alves et al., 2002, 2006]. No evidence of thin-skinned tectonic inversion is observed on seismic data. Inversion structures chiefly comprise low-amplitude folds and thrust faults within Mesozoic and Cenozoic successions, chiefly in the westernmost (deeper) part of the outer proximal margin (Figure 8). Consequently, large parts of the study area were covered by thick sucessions of hemipelagic, turbidite and contourite units from the start of the Miocene [Alves et al., 2003a]. Erosion and gentle folding on the inner proximal margin accompanied basin inversion, and resulted in the formation of small synclines filled by thin $(<0.4 \mathrm{~s}$ twtt $)$ Miocene strata (Figure 12).

[37] Figure 12 illustrates one of the regions where inversion is prominent. Well Pe-1 (Figure 11) is $3 \mathrm{~km}$ from the northernmost edge of this seismic line, but can still be tied to interpreted seismic units. Mesozoic normal faults occur toward the continental shelf and slope. Rift-related structures in the outer proximal margin were reactivated as reverse faults (Figures 8 and 12). Onlap and pinch-out geometries onto some of these faults clearly relate the onset

Figure 7. (a) Near base Late Jurassic isopach data and (b) corresponding structural map of the Alentejo Basin. The location of principal depocenters offshore southwest Iberia are highlighted in the figure. Note the presence of the slopebounding fault system (SFS) at approximately $09^{\circ} 45^{\prime} \mathrm{N}$. 

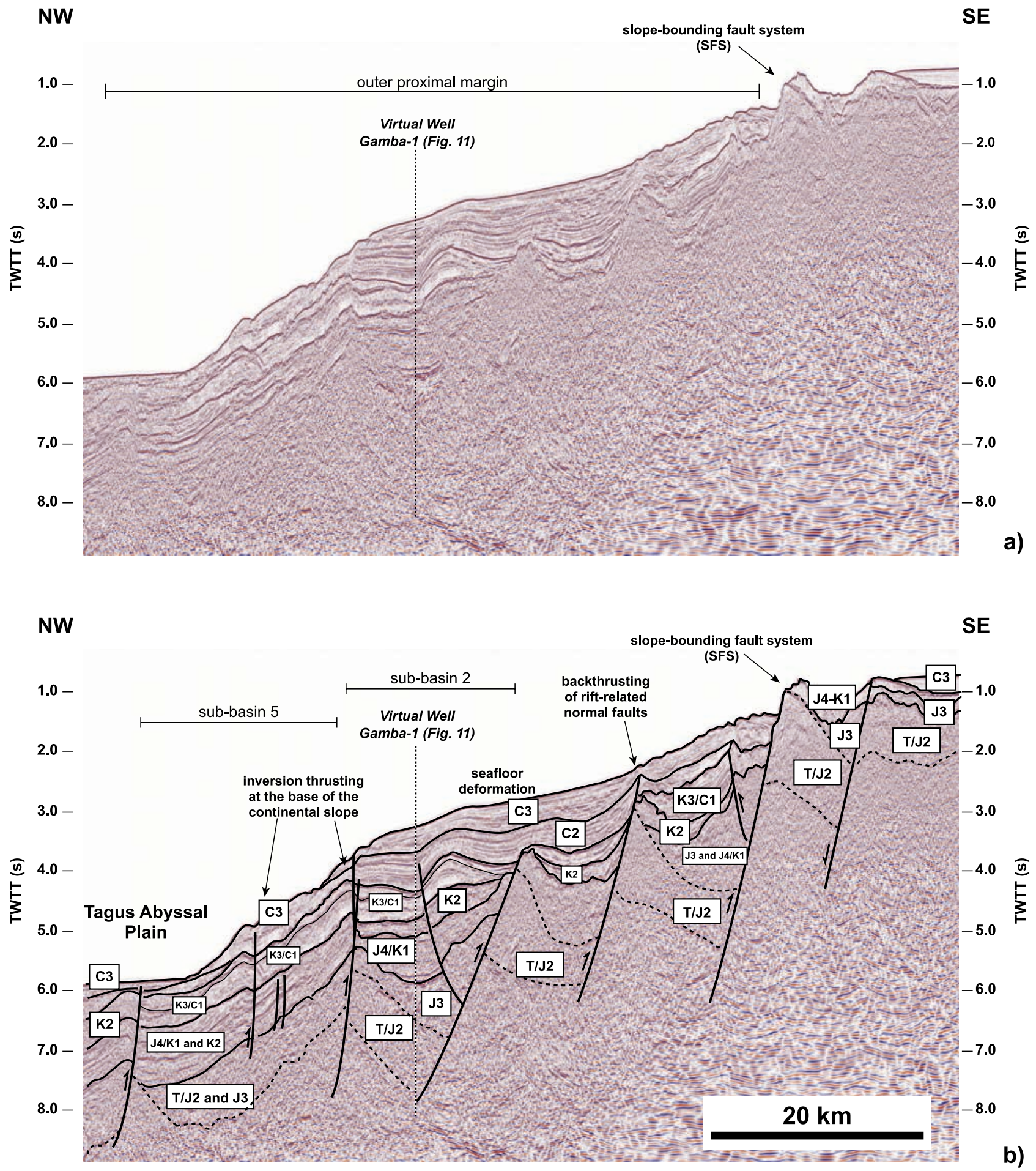

Figure 8. (a) Seismic section and (b) corresponding interpretation of a NW-SE seismic profile crossing the continental slope of southwest Iberia (see Figure $1 \mathrm{~b}$ for location). The development of multiple tilt blocks west of the SFS is depicted, with localized inversion occurring in relation to back thrusting of basin-bounding normal faults. Virtual well Ga-1 is shown in detail in Figure 11. Seismic line courtesy of TGS/NOPEC Geophysical Company. 

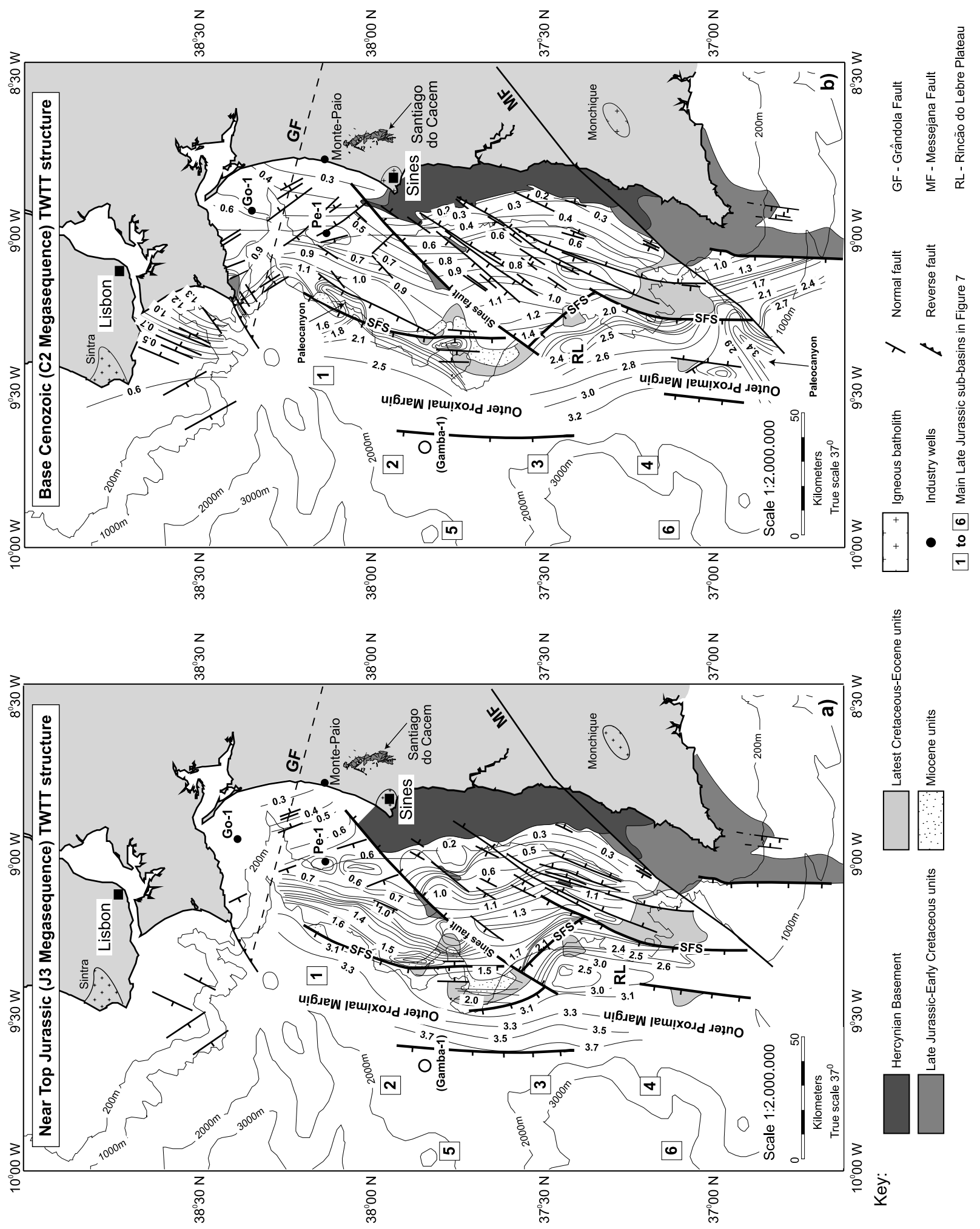
of inversion to the Cenozoic, as most of the latter geometries are not observed in $\mathrm{K} 3 / \mathrm{C} 1$ but in $\mathrm{C} 2$ and $\mathrm{C} 3$ (Figure 12).

[38] In summary, Cenozoic deformation on the outer proximal margin includes (1) localized back thrusting of basin-bounding normal faults and (2) shortening of MesoCenozoic strata against basin-bounding footwall blocks, which formed structural buttresses (Figure 8). Shortening approaches $10 \%$ in parts of the study area, with an average value of $\sim 5 \%$, a value lower than that recorded in the Lusitanian Basin [Alves at al., 2003c] where thin-skinned inversion is prominent [Wilson et al., 1989; Canérot et al., 1995]. In addition, thrusting is clearly diachronous throughout the margin: some thrusts are blanketed by subhorizontal late Cenozoic strata showing thickening of strata in Miocene and older units. Other similar structures deform the seafloor and show no stratal thickening, being locally associated with flower structures recording lateral (strikeslip) movement [e.g., Harding, 1985]. On the inner proximal margin, high-amplitude folds are chiefly recorded in pre-Miocene strata and followed the formation of a widespread angular unconformity dated as late ChattianAquitanian [Alves et al., 2003a]. Locally, seafloor deformation is observed, demonstrating that significant tectonic movements occurred in the Holocene (Figure 8).

\section{Controls on the Morphology of Lower Plate Margins}

[39] A key aspect revealed on seismic data is the marginal position of the inner proximal margin during continental rifting, with the SFS separating this latter region from highly extended tilt blocks in the deep offshore (Figure 8). Several rift basins, including those in the Gulf of Suez [Khalil and McClay, 2001], Red Sea-Afar rift [Acocella et al., 2008] and southern Africa (Botswana [Kinabo et al., 2008]) show a similar geometry to west Iberia, with major normal faults separating a proximal region from axial extensional basins where the bulk of synrift basement subsidence is recorded. These fault lineaments, or rift border faults in the sense of Khalil and McClay [2001], can merge to form continuous normal fault segments typically $25 \mathrm{~km}$ to $325 \mathrm{~km}$ long [Kinabo et al., 2008]. In the Gulf of Suez they are associated with the migration of rifting toward distal parts of the continental margin prior to continental breakup and subsequent formation of oceanic crust.

[40] Examples of highly segmented rift margins of the ancient Tethys Ocean are exposed in the Alps [Froitzheim and Manatschal, 1996; Manatschal and Bernoulli, 1998; Manatschal, 2004]. One of these regions, the Ligurian Basin, is compared in Figure 13 with the interpreted evolution of the southwest Iberian margin during the Triassic-Early Cretaceous. Like the Ligurian Basin, mod- erate normal faulting and widespread basement subsidence is believed to have occurred in southwest Iberia during the first rifting episodes (rifts 1 and 2), i.e., during the early rifting stage of Manatschal and Bernoulli [1998, 1999]. At the onset of Late Jurassic-earliest Cretaceous extension (rift 3), Oxfordian-early Kimmeridgian rift basins were formed on the inner and outer proximal margins, while tilt blocks on the outer proximal margin formed highly subsiding subbasins during the advanced rifting stage (Figures 8 and 13).

[41] We interpret subsequent phases of tectonic quiescence, widespread erosion and sediment progradation on the inner proximal margin as marking the abandonment of extensional basins east of the SFS, and the subsequent continuation of synrift extension on the outer proximal margin. As a result, north trending structural highs, separating the inner proximal margin from locus of rifting west of the SFS, were formed close to the future shelf edge area [e.g., Alves et al., 2006]. In the particular case of the Lusitanian Basin, the uplift of its western rift shoulder is recorded by the progradation of sediment from the west, particularly during the deposition of the Lourinhã (late Kimmeridgian-Berriasian) and Torres Vedras formations (late Berriasian-Aptian) [Wilson et al., 1989; Alves et al., 2003b] as explained in more detail in section 9. For comparison, a major Berriasian-Aptian hiatus is documented in the northern sector of the Lusitanian Basin where, through most of the Early Cretaceous, a tectonically uplifted rift shoulder evolved in what is presently the continental shelf region north of the Nazaré Fault [e.g., Alves et al., 2002].

[42] Considering the structural evolution of the Gulf of Suez and Ligurian Basin, where similar modes of extension to west Iberia are recorded prior to continental breakup [Froitzheim and Manatschal, 1996; Michon and Merle, 2003], marginal horsts form the structural boundary of outcropping, or shallow marine, inner proximal basins developed during the early stages of continental rifting. Seismic data from southwest Iberia and Peniche support the notion that proximal regions form rift shoulder areas to active extensional basins in the outer proximal margin and effectively record the principal rift-related tectonic events affecting lower plate margins such as west Iberia (Figure 13). Also, the deposition of prograding slope units, with the SFS marking the edge of the continental shelf since the cessation of continental rifting, confirms that the current morphology of the entire west Iberia margin was created during rifting that occurred as early as the Late Jurassic (rift 3) in southwest Iberia and the Early Cretaceous (rift 4) in northwest Iberia. Finally, by understanding the rift-related evolution of its northwest and southwest margins, we can infer the timings of continental rifting and breakup for central west Iberia, and thus complete the currently published tectonosedimentary models for the Lusitanian Basin

Figure 9. Two-way traveltime structure maps for units deposited on the inner proximal margin: (a) near-top Jurassic time structure map, (b) near-base Miocene time structure map. The location of the Sines Fault and the six principal depocenters referred to in the text are highlighted. 

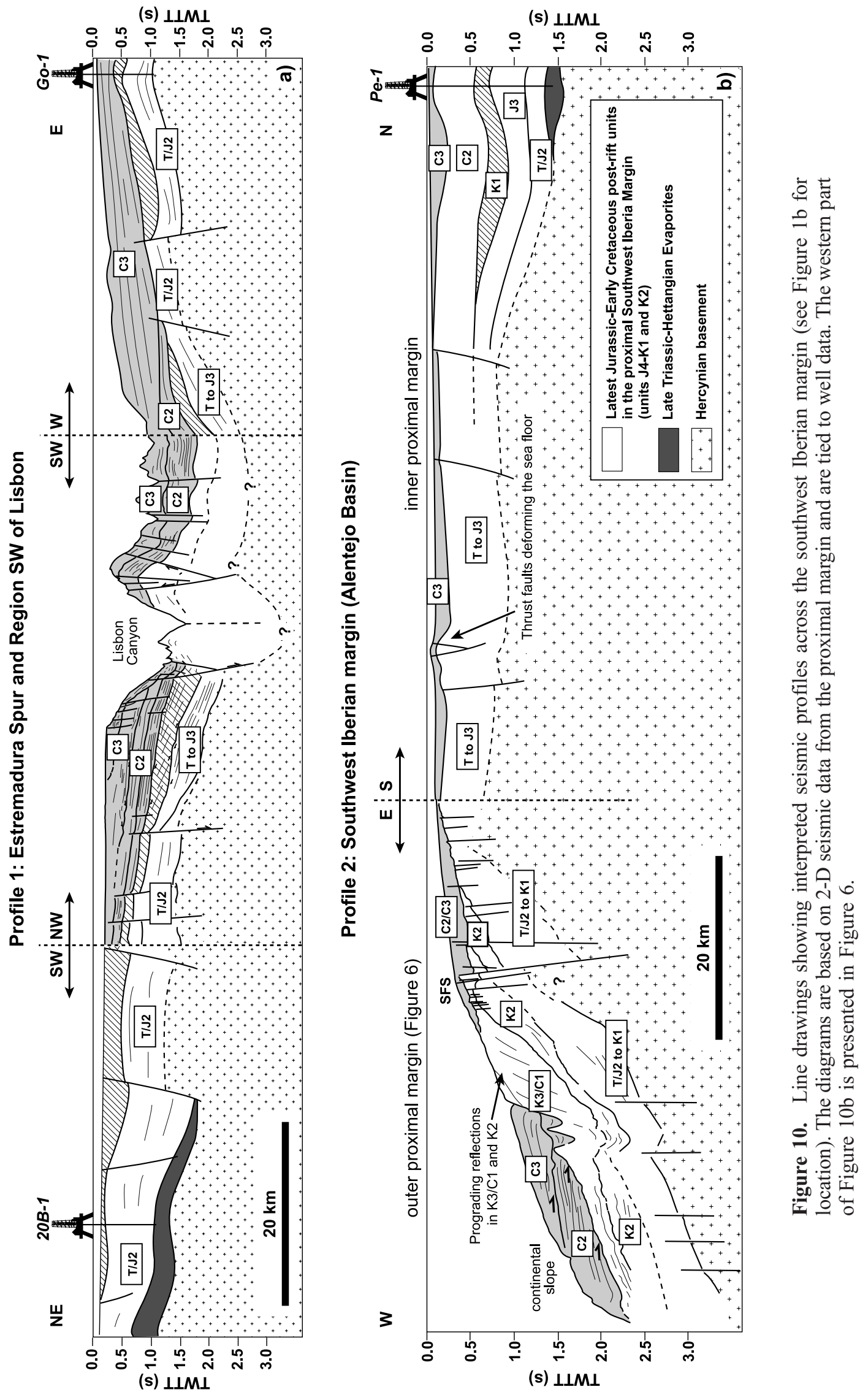

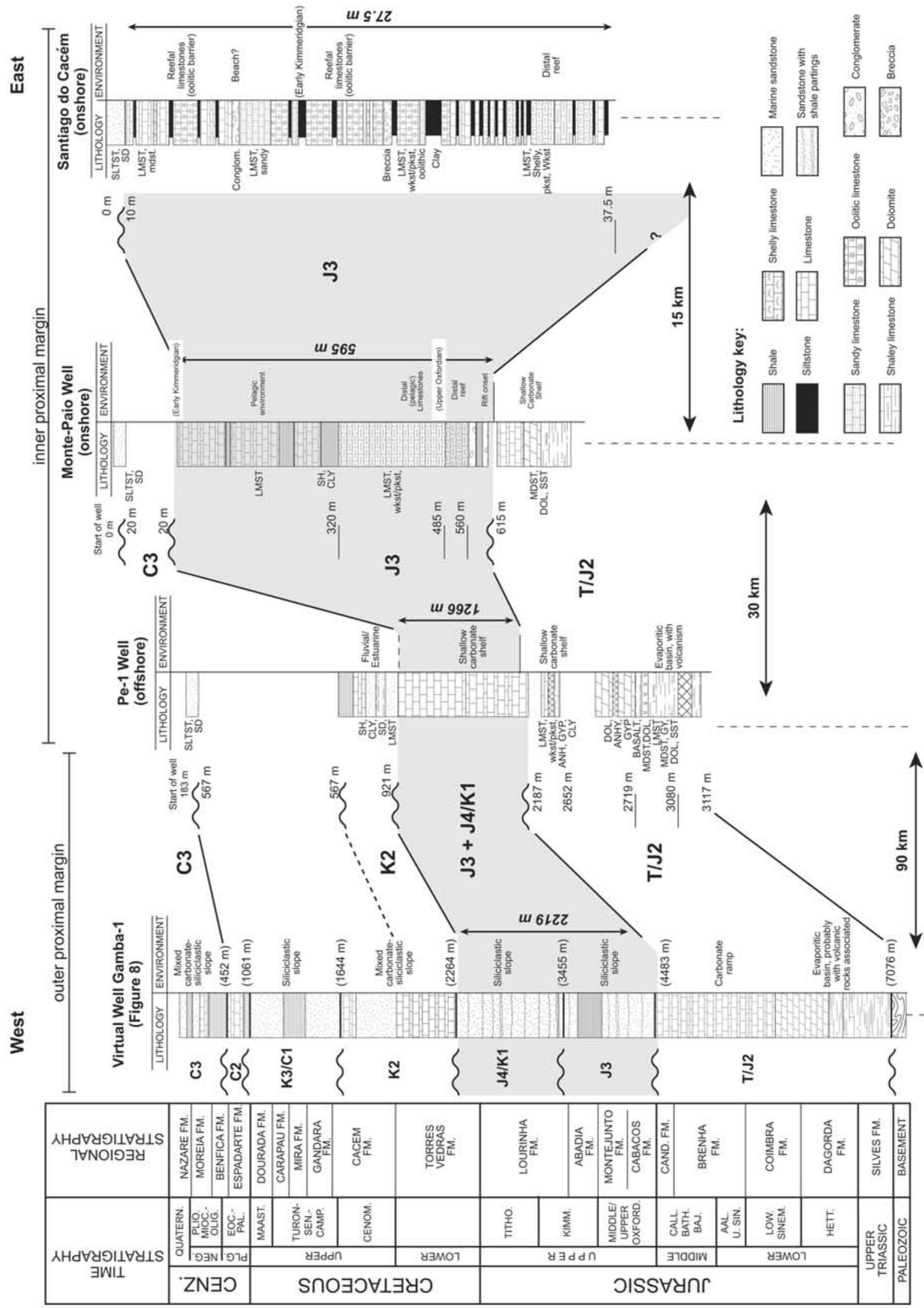

高

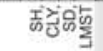

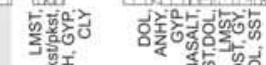

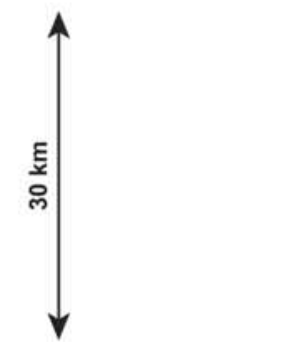

$=$ 

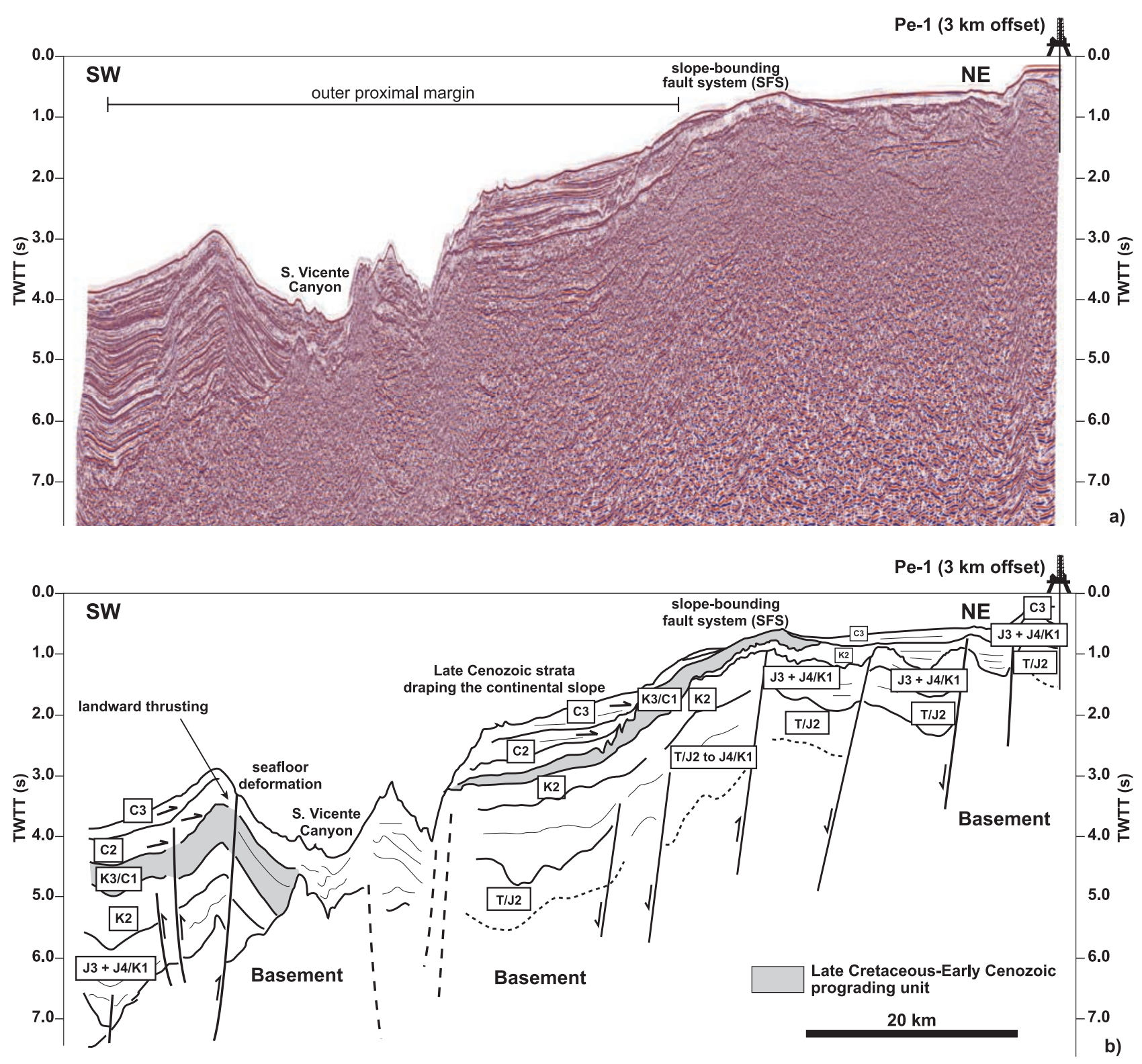

Figure 12. (a) Seismic section and (b) corresponding interpretation of an NE-SW seismic line across the southern portion of the study area (see Figure $1 \mathrm{~b}$ for location). Well Pe-1 is offset $3 \mathrm{~km}$ to the north of the seismic line. The profile depicts the structural style of inversion structures in the study area, in relation to the absence of buried evaporite successions in southwest Iberia. Note the absence of developed thrust faults on the outer proximal margin northeast of the São Vicente Canyon. Seismic line courtesy of TGS/ NOPEC Geophysical Company.

Figure 11. Correlation panel between relevant outcrop and well data from the Alentejo Basin. Onshore data based on original logs from the Santiago do Cacém region (Figure 1b). The relative location of virtual well Gamba-1 is shown in Figures $1 \mathrm{~b}$ and 8 . 

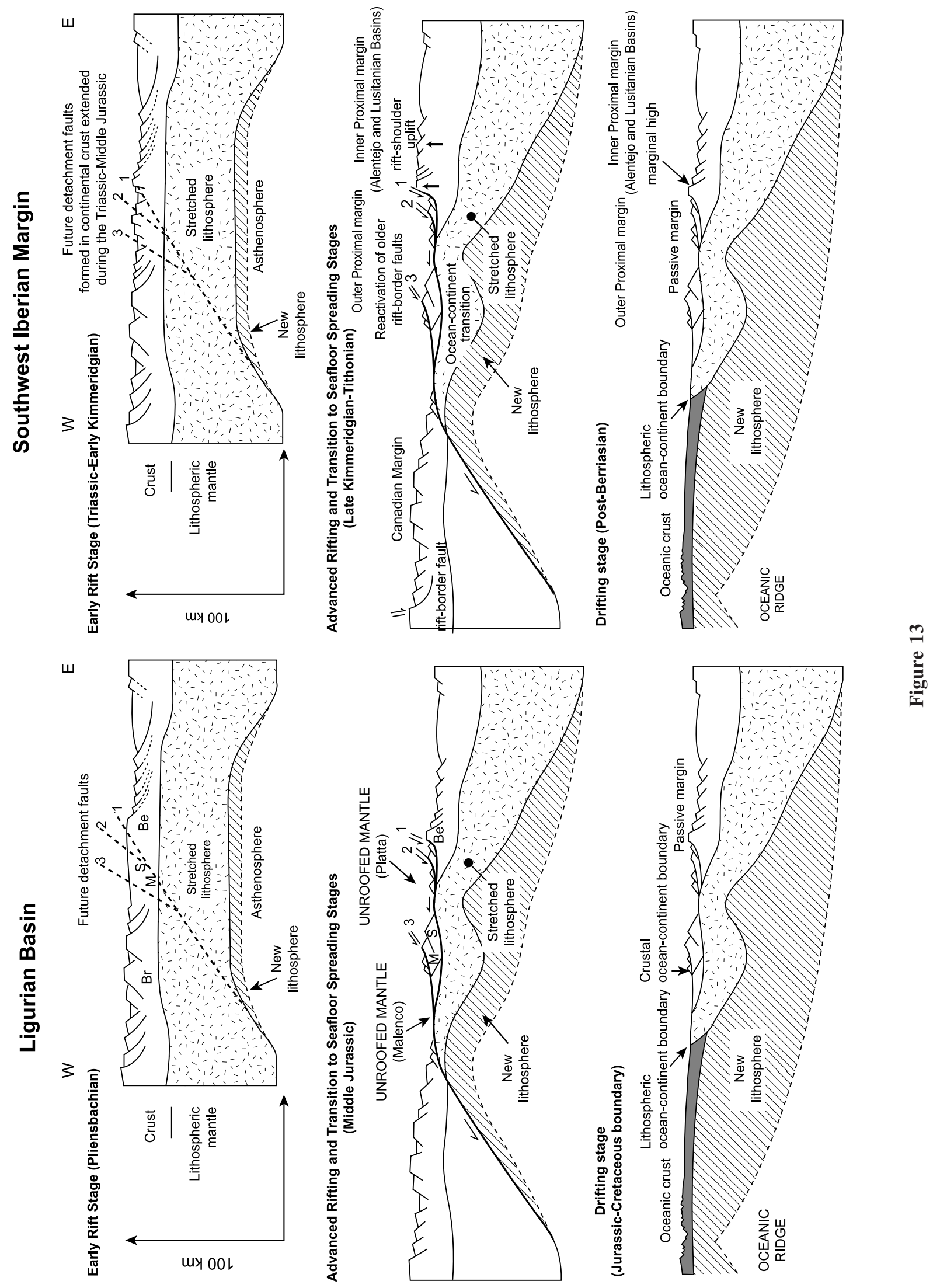
North

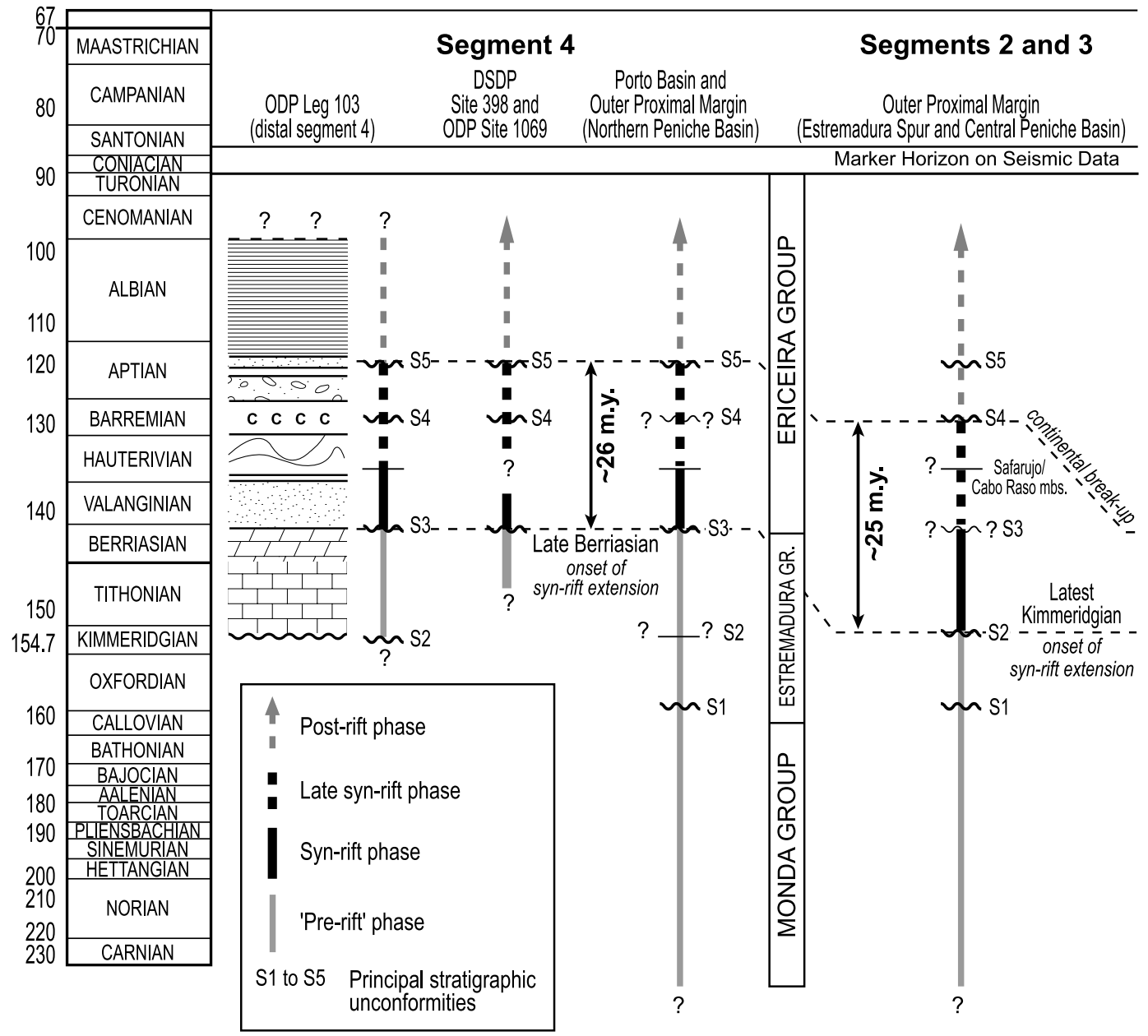

Lithology for onshore Lusitanian Basin and offshore wells

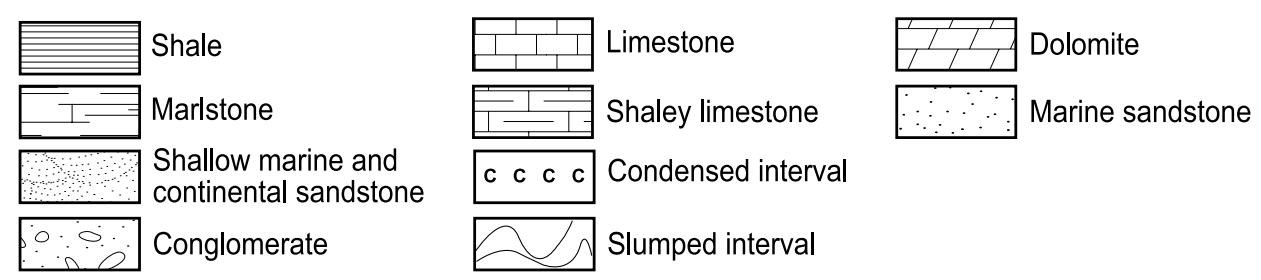

Figure 14. Correlation panel among interpreted S1 to S5 unconformities and the stratigraphy of the Lusitanian Basin. Formation names are informal and based on the work by Wilson et al. [1989]. ODP data from Leg 103 from Boillot et al. [1989]. DSDP information from Groupe Galice [1979]. Data from ODP Site 1069 from Wilson et al. [2001].

Figure 13. Diagram comparing the kinematic evolutions of passive margins in the (a) Tethyan Ocean (Ligurian Basin) and (b) southwest Iberia. Prerift, synrift, and postrift sedimentary units are neglected. "Stretched lithosphere" is prerift continental lithosphere; "new lithosphere" is synrift or postrift lithosphere derived from cooling asthenosphere. Be, Bernina; Br, Briançonnais; M, Margna; S, Sella. Modified from Froitzheim and Manatschal [1996]. 


\section{South}

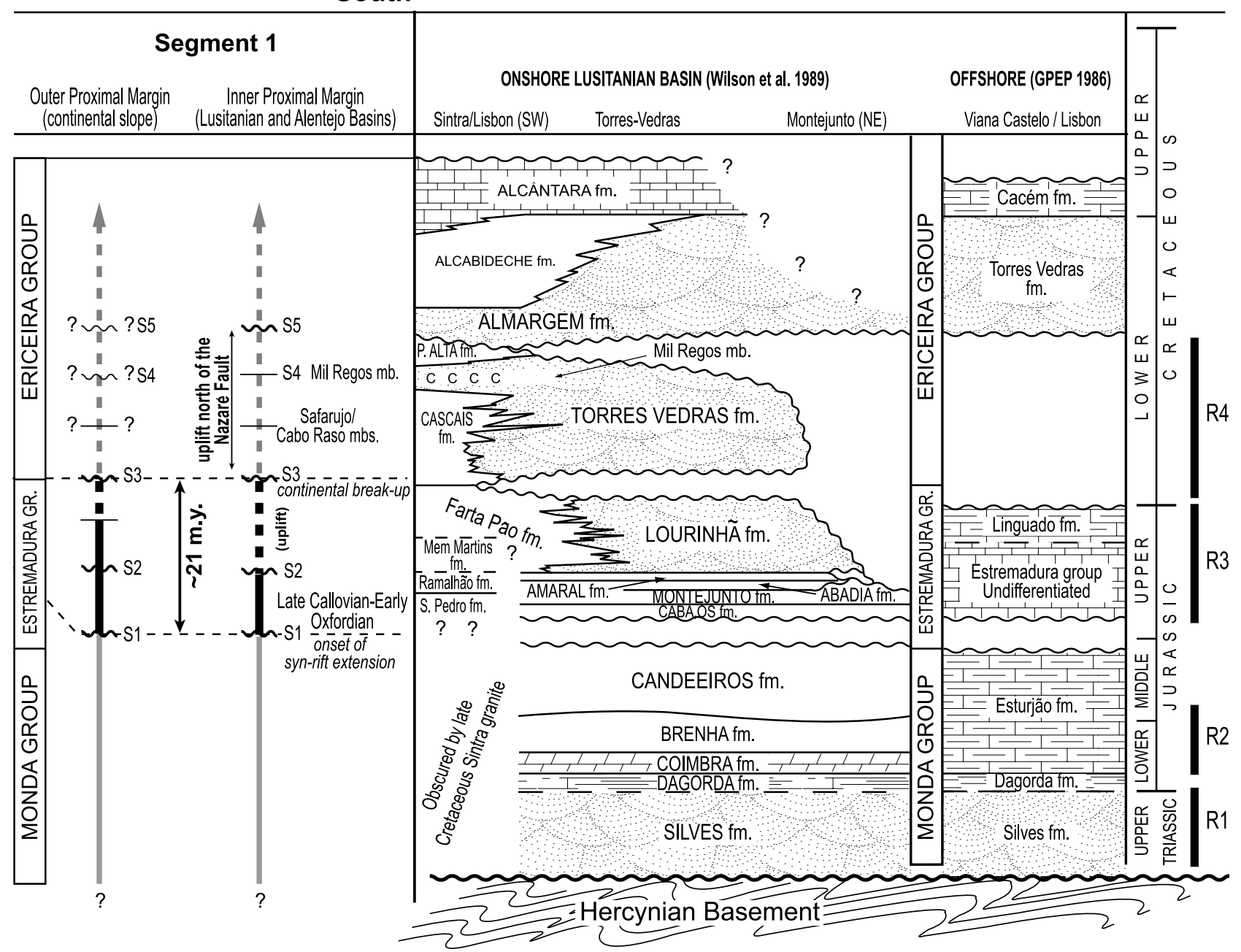

R1 to R4 - Principal extensional episodes as defined by Rasmussen et al. [1998] and Alves et al. [2002; 2006] based on data from the Lusitanian and Peniche Basins.

Figure 14. (continued)

[e.g., Wilson et al., 1989; Rasmussen et al., 1998], the Peniche Basin [Alves et al., 2006] and the Newfoundland margin [Tucholke and Sibuet, 2007].

\section{Discussion}

\subsection{Stratigraphic Markers in Inner Proximal Basins}

[43] Main basinwide unconformities in inner and outer proximal basins are presented in Figure 14. In the correlation panel, we use the pervasive Cenomanian-Turonian horizon as stratigraphic marker, which is characterized by the deposition of deep marine carbonates on the inner proximal margin and by hemipelagite deposition in the Iberia Abyssal Plain [Rasmussen et al., 1998; Wilson et al., 2001]. The diachronous episodes of continental rifting and breakup that affected west Iberia are illustrated in
Figure 15, based on data in this paper and in the work by Alves et al. [2006].

[44] As in the conjugate Jeanne D'Arc Basin, distinct extensional and breakup events are recorded in west Iberia as major unconformities and/or basinwide shifts in facies, as seen both in seismic and well data [Hiscott et al., 1990a; Alves, 2002]. In the Lusitanian Basin, most of these unconformities have been interpreted as reflecting tectonic movements due to rapid thinning and thermal uplift of the crust during extension and/or compressional intraplate deformation, while eustatic conditions had little effect on sedimentation [Wilson et al., 1989; Hiscott et al., 1990a] (Figure 16). Therefore, the interpreted unconformities in Figure 14 reflect five (5) Oxfordian-Aptian "regressive events" (S1 to S5) associated with tectonic uplift and relative sea level fall in inner proximal basins [Leinfelder and Wilson, 1998; 


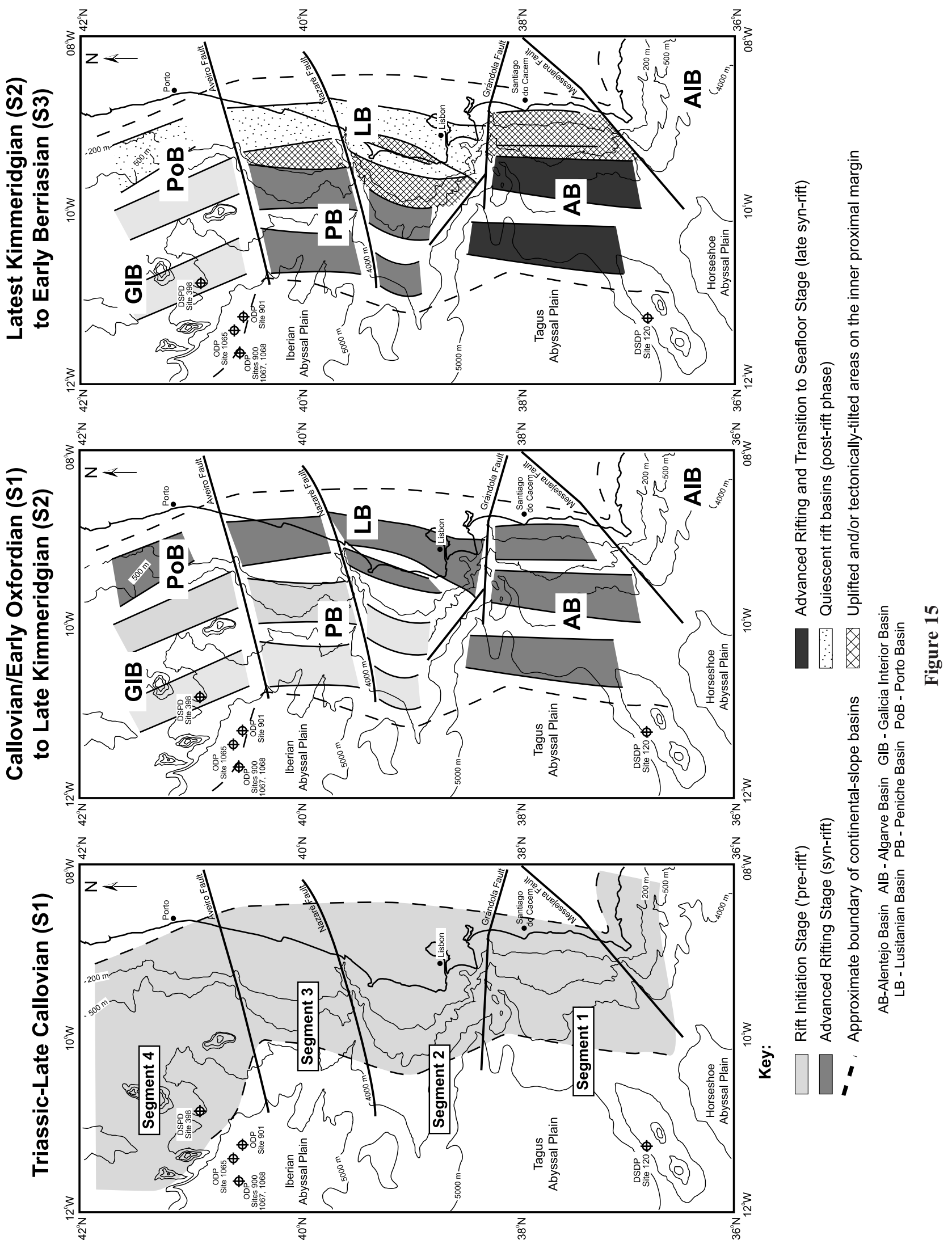


Wilson et al., 1989; Alves et al., 2002; Alves, 2003b] (Figures 13 and 14).

[45] Our interpretation does not exclude, in localized subbasins, the prolongation of synrift subsidence (or, in contrast, its early cessation) away from the interpreted stratigraphic boundaries, as documented in parts of the North Atlantic [Driscoll et al., 1995; Sinclair, 1995]. Likewise, the stratigraphic expression of equivalent riftrelated tectonic events may vary within, and among (1) distinct deep offshore basins, (2) separate crustal segments, and (3) conjugate pairs of margins [Hiscott et al., 1990a; Welsink and Tankard, 2009]. Also, the complex structure of rift basins can also contribute to the formation of diachronous stratigraphic surfaces, particularly in marginal areas to subsident subbasins, over salt structures, and/or above main structural highs, as demonstrated by Wilson et al. [1989] and Leinfelder and Wilson [1998] for the Lusitanian Basin.

[46] All the margin segments show a relatively uniform Triassic-Middle Jurassic evolution, with carbonate deposition prevailing in all inner proximal basins (Figure 15). In segment 1, a Callovian-early Oxfordian unconformity (S1) precedes the onset of Late Mesozoic rifting as recorded on the inner proximal margin (Figures 14 and 15). A similar unconformity marks the onset of a principal late CallovianBerriasian episode of extension (episode 1, rift 2) on the Newfoundland margin [Tucholke and Sibuet, 2007]. Middle Oxfordian strata occur at the base of the Late Jurassic successions in the Porto and Lusitanian basins [Inverno et al., 1993; Alves et al., 2003b; C. Moita et al., Porto Basin: Seismic interpretation report, unpublished report, MILUPOBAS project, 1996]. In contrast to the inner proximal margin, the basal rift onset unconformity has been dated as late Berriasian-Valanginian on the outer proximal margin of segment 4 [Wilson et al., 2001] (Figure 14). Subsidence in the Lusitanian Basin peaked in the OxfordianKimmeridgian boundary and is associated with surface fault propagation and erosion of adjacent carbonate platforms [Wilson et al., 1989, Alves et al., 2003b]. An equivalent, synchronous event is recorded in the Porto Basin (C. Moita et al., Porto Basin: Seismic interpretation report, unpublished report, MILUPOBAS project, 1996).

[47] By the end of the Kimmeridgian (end of mutabilis/ acanthicum biozones [Atrops and Marques, 1986]), a relative sea level fall occurred on the inner proximal margin (S2) [Alves et al., 2002, 2003b]. At this time, subsidence curves for the Lusitanian Basin show a short tectonic pulse associated with the uplift of its western rift shoulder area (Berlengas Horst) [Hiscott et al., 1990a] (Figure 16). In addition, the S2 event marks the base of locally unconformable deltaic to alluvial/fluvial deposits prograding into the basin from the west [Hill, 1989; Alves et al., 2003b].

[48] On a regional scale, strata overlying S2 are grouped in the Lourinhã formation [Wilson et al., 1989], interpreted here as reflecting sediment progradation on the inner proximal margin in response to marginal uplift of rift shoulder areas due to the onset of extension on the outer proximal margin west of the Lusitanian Basin (Figures 14 and 15). Consequently, sediment accommodation space in the Lusitanian Basin was mostly filled by the late Berriasian (late postrift stage [Alves et al., 2003b]), prior to a third (S3) basinwide unconformity (Figure 14).

[49] We interpret S3 as marking the onset of (postrift) tectonic quiescence in inner proximal basins, with the exception of the Porto Basin (C. Moita et al., Porto Basin: Seismic interpretation report, unpublished report, MILUPOBAS project, 1996). Associated with S3 are (1) continental breakup in the Tagus Abyssal Plain and (2) the onset of the final rifting episode (rift 4) in segment 4 (Figures 14 and 15). After S3, subsidence was markedly reduced in the Lusitanian Basin [e.g., Hiscott et al., 1990a], while a passive margin was already established in most of southwest Iberia. Continental deposits covered a great part of the southern Lusitanian Basin until the Valanginian, followed by marine/transitional strata recording an earliest Hauterivian transgression maximum [Dinis et al., 2008]. A simpler facies distribution, with no major variations in thickness, is recorded west of Lisbon after the early Hauterivian, above a maximum flooding surface marked by the Safarujo/Cabo Raso members [Hiscott et al., 1990b; Rey et al., 2006] (Figure 14).

[50] On the basis of the presence of two regional tectonic events (S2 and S3) in west Iberia, we propose Late Jurassic-Cretaceous continental rifting west of the Lusitanian Basin to have comprised two distinct pulses. In segments 2 and 3, a first latest Kimmeridgian-Tithonian extensional episode recorded the onset of rifting north of $38^{\circ} 30 \mathrm{~N}$ (Figure 15). This latter event is marked at ODP Site 1069 [Wilson et al., 2001] and in Leg 103 (distal Galicia margin [Boillot and Winterer, 1988]) by the deposition of Tithonian shallow marine carbonates. It also agrees with late Kimmeridgian (prerift) extensional faulting documented on the western and southern Galicia Bank [Clark et al., 2007] (Figure 14). This latter extensional episode preceded Berramian (S4) continental breakup at $\mathrm{N} 40^{\circ} 15^{\prime}$ (segment 3) [Whitmarsh and Miles, 1995], $\sim 10$ Ma before late Aptian breakup in segment 4 where a stretching maximum is recorded during the Valanginian [Groupe Galice, 1979; Murillas et al., 1990; Boillot et al., 1995] (Figures 14 and 15). Therefore, extension during the advanced rifting stage is interpreted to have occurred before the Valanginian in segments 2 and 3, thus correlating synrift successions on the outer proximal margin west of the Lusitanian Basin with equivalent synrift strata in the Jeanne D'Arc Basin [e.g., Sinclair, 1995]. These considerations agree with the interpreted seismic data, in which two distinct rifting axes are recognized in west Iberia (Figure 15). A first axis relates to Oxfordian-earliest Cretaceous continental rifting and extends from the Porto Basin to the southwest Iberian margin. A second axis (axis 2, Figure 15) relates to late Kimmeridgian to Aptian rifting, extending from the Estre-

Figure 15. Interpreted evolution of continental rifting on the west Iberia margin. The figure highlights the presence of two distinct Late Jurassic-Aptian rift axes. The relative location of sedimentary basins on the continental slope was based on seismic data sets in this paper and in the work by Alves et al. [2003a, 2006]. 

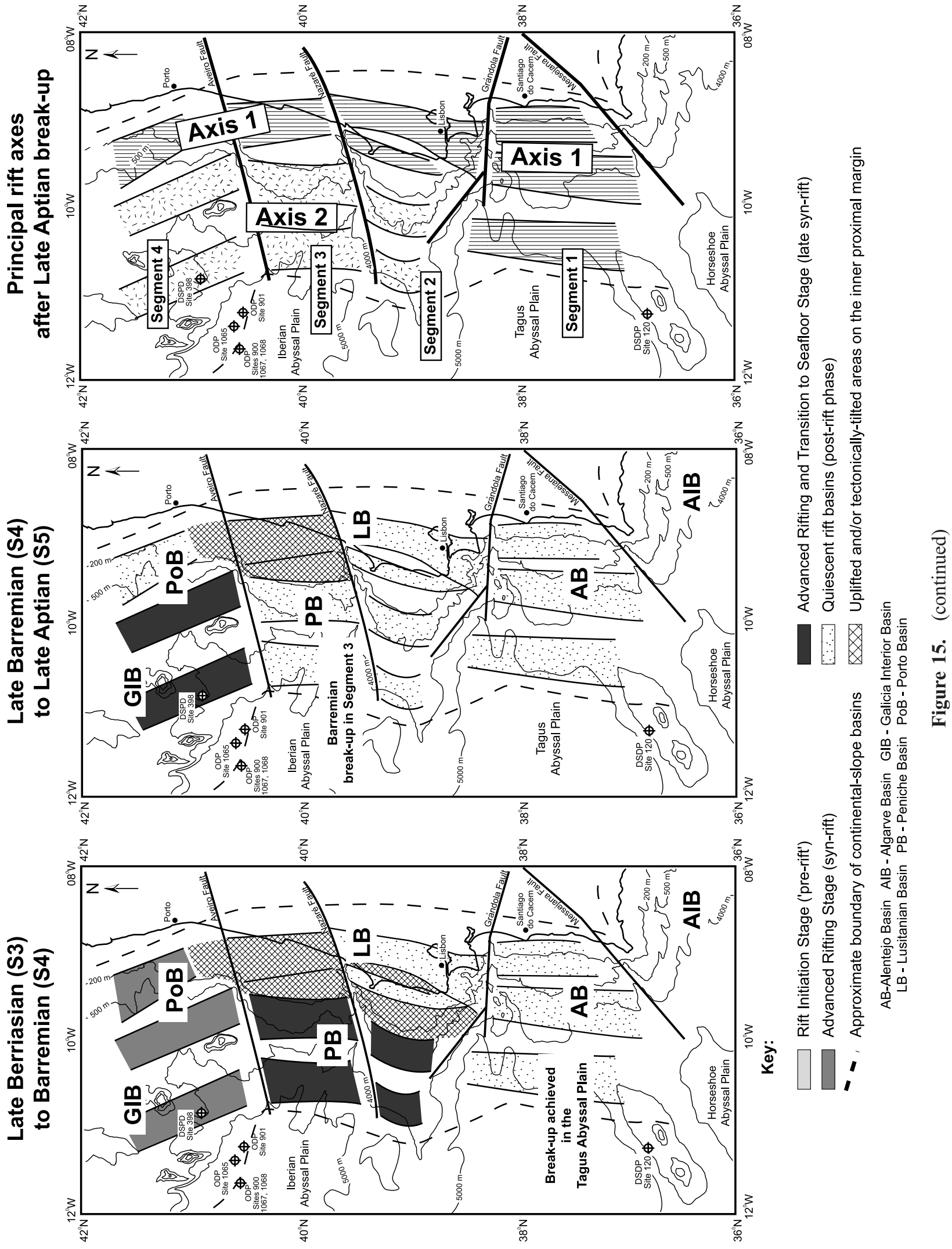


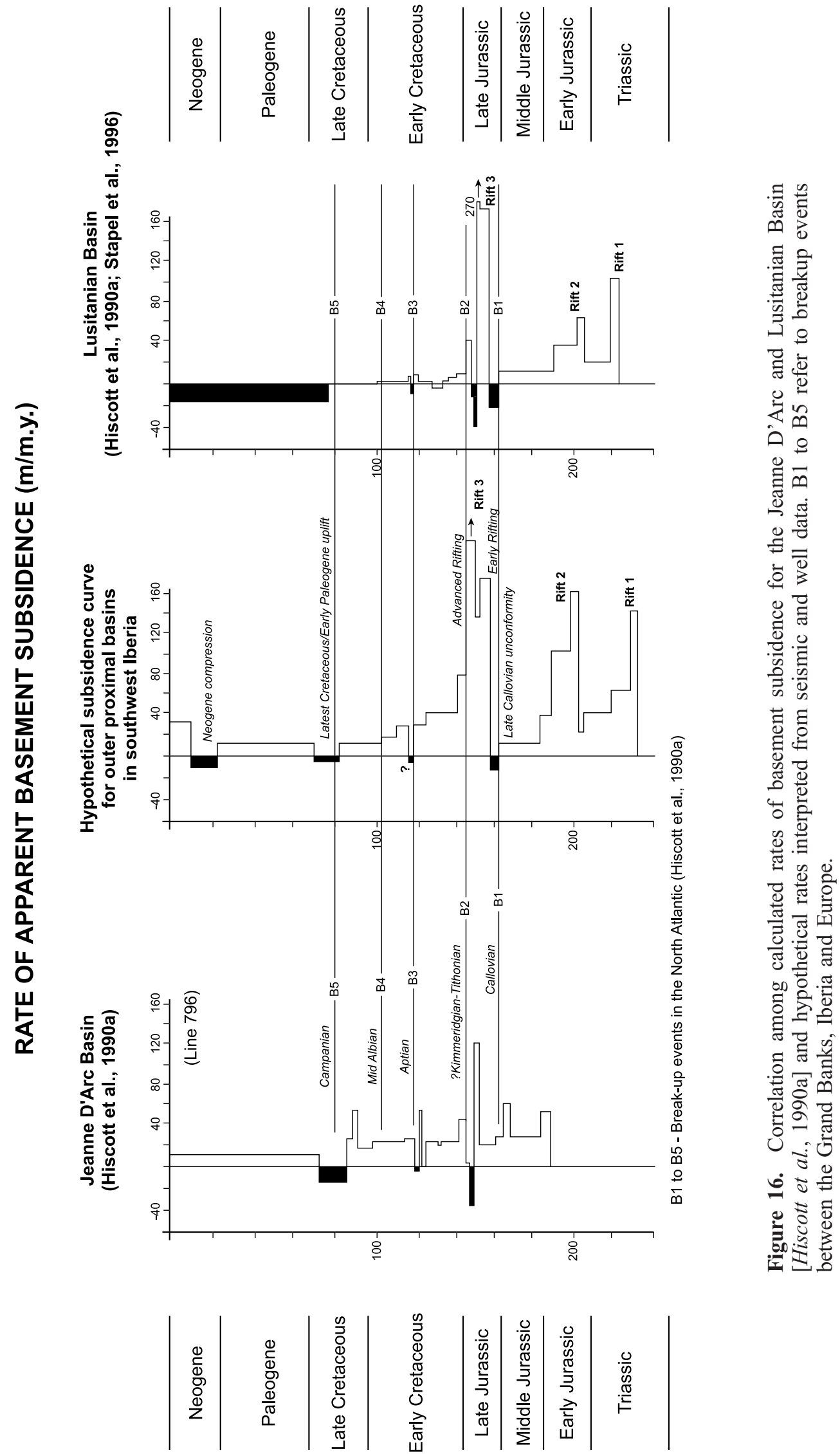




\section{Northwest lberian Margin (Peniche Basin)}

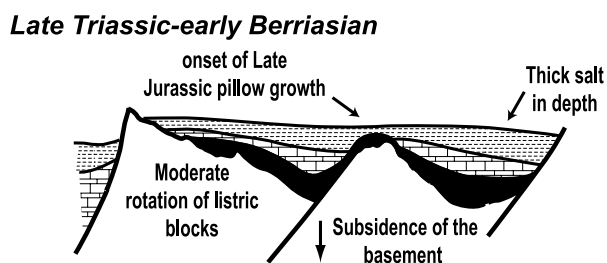

\section{Late Berriasian-Aptian}
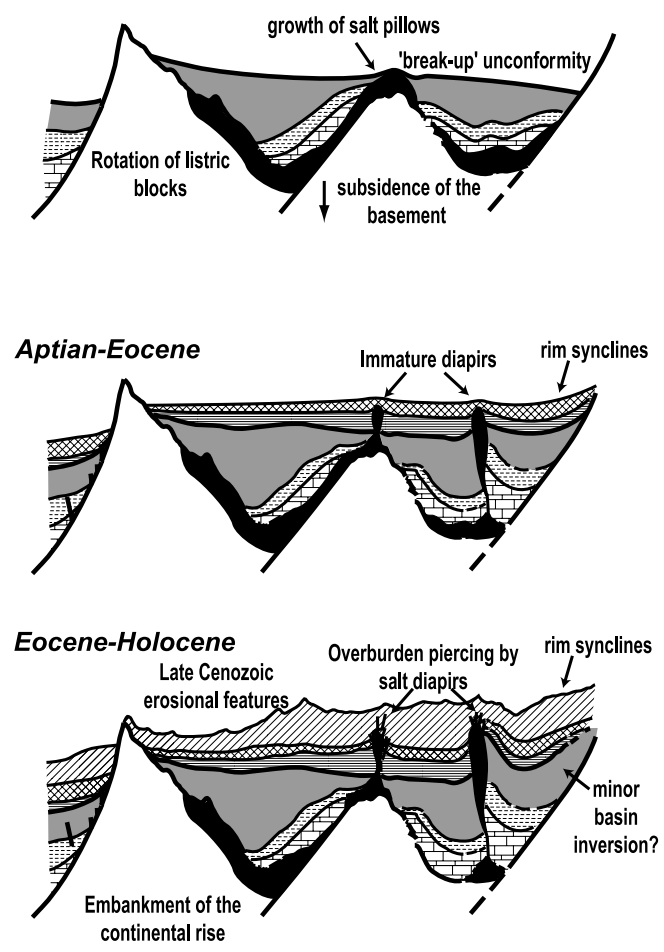

\section{Southwest Iberian Margin (Alentejo Basin)}

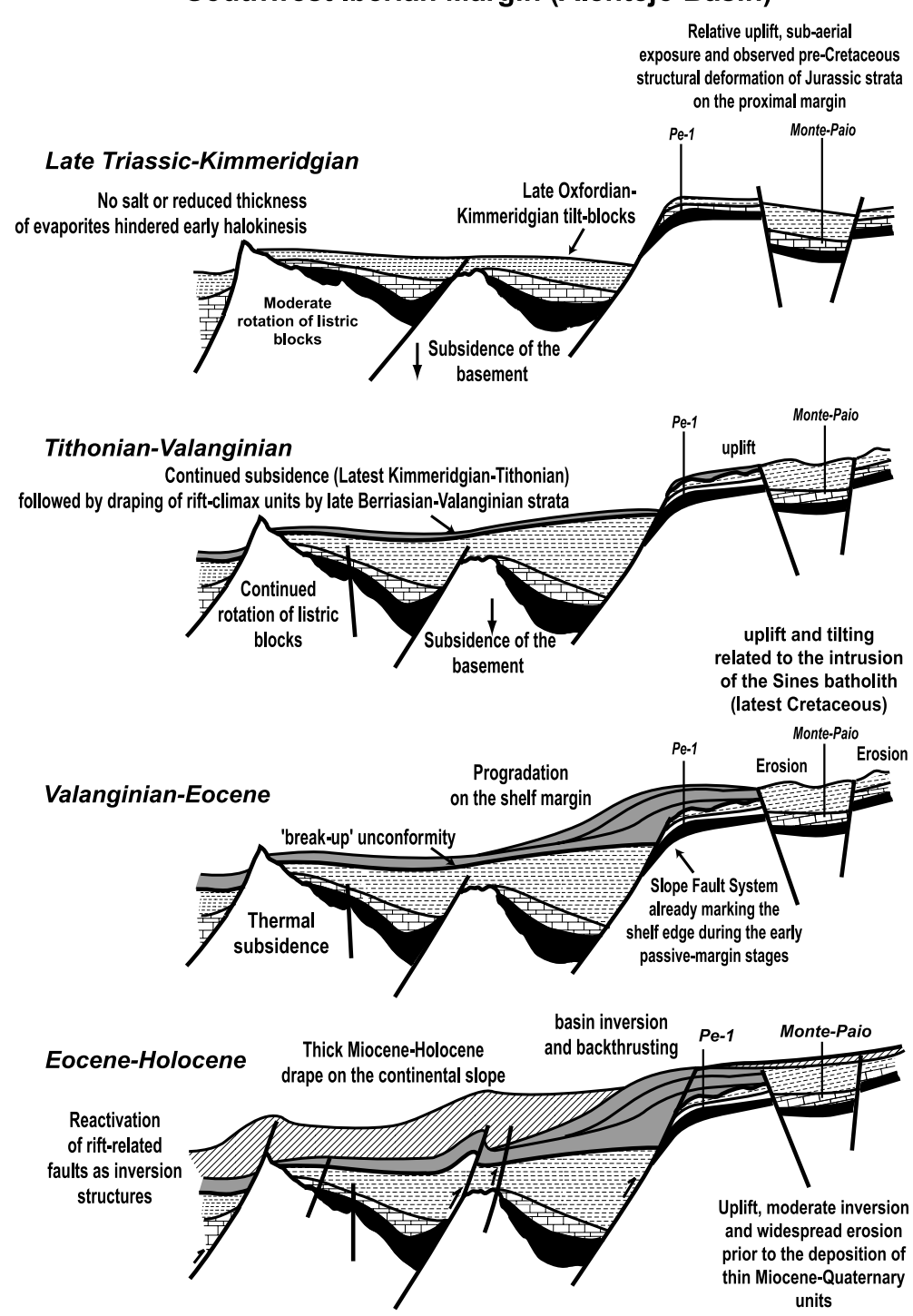

Key for Peniche Basin:

Key for Alentejo Basin:

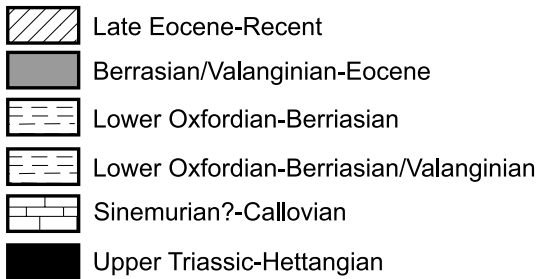

Upper Triassic-Hettangian

Figure 17. Diagram illustrating the comparative tectonosedimentary evolution of the Peniche and Alentejo basins.

madura Spur (segment 2) to the Galicia Bank (segment 4). Separating the Tagus Abyssal Plain from axis 2, a major structural lineament should have developed along the west Iberian margin south of the Estremadura Spur (Figure 15).

\subsection{Subsidence on the Outer Proximal Margin}

[51] Why is the thickness of synrift strata greater on the outer proximal margin when compared with the Lusitanian and Porto basins (inner proximal margin)? On the basis of the presence of highly rotated tilt blocks west of the SFS, 
filled with up to $3.0 \mathrm{~s}$ twtt of prerift and synrift strata, three distinct explanations can be evoked. A first explanation relates to greater rates of basement stretching and subsidence occurring on the outer proximal margin, particularly during the extensional episodes that led to continental breakup (rifts 3 and 4). The inner proximal margin may only record a fraction of the tectonic subsidence of deep offshore basins: The more than $270 \mathrm{~m} / \mathrm{Ma}$ of subsidence calculated for the Lusitanian Basin around the OxfordianKimmeridgian boundary (Arruda subbasin [Wilson et al., 1989; Hiscott et al., 1990a]) may have been followed by much greater subsidence rates on the outer proximal margin (Figure 16). However, this first explanation is contradicted by the smaller rates of subsidence recorded in the Jeanne D'Arc Basin, ranging from 40 to $120 \mathrm{~m} / \mathrm{Ma}$, which resulted in the accumulation of substantially thicker synrift successions than in the Lusitanian Basin (Figure 16). Such a discrepancy between the thicknesses of synrift strata in the two basins has been interpreted as an example of distinctive rift-related evolutions in conjugate passive margins, a factor responsible for longer periods of basement subsidence offshore Canada when compared to the Lusitanian Basin [Hiscott et al., 1990a; Leinfelder and Wilson, 1998]. The data considered in this work indicates that (1) the Lusitanian Basin was not in an equivalent position to the Jeanne D'Arc Basin when the final rifting episodes affected west Iberia (i.e., comprised an interior rift basin in the sense of Manatschal and Bernoulli [1999]) and, (2) only outer proximal basins in segments 2 and 3 should be compared with the latter basin in terms of their subsidence histories (see section 9.3).

[52] A second possibility is that basins on the outer proximal margin record longer (but not necessarily greater) episodes of basement stretching and subsidence when compared to the inner proximal margin. This way, synrift strata filling outer proximal basins would result from a prolonged extensional episode, perhaps spanning from the early rifting stage until continental breakup (Figure 14). Although it explains the greater thickness of synrift strata in outer proximal basins, this interpretation is incompatible with the age difference between the deposition of synrift strata in inner proximal basins (Oxfordian-Kimmeridgian in the Lusitanian and Porto basins [Alves et al., 2003b; C. Moita et al., Porto Basin: Seismic interpretation report, unpublished report, MILUPOBAS project, 1996]) and synrift units in outer proximal basins in segment 4, interpreted to span the late Berriasian-late Aptian [Boillot et al., 1995; Wilson et al., 2001]. Also, it does not fit with seismic reflection and well data from the entire west Iberian margin, in which a clear stratigraphic boundary separates prerift strata from synrift units on the outer proximal margin, i.e., dividing units deposited during the early rifting stage from strata accumulated in the advanced rifting stage [e.g., Groupe Galice, 1979; Boillot et al., 1989; Pinheiro et al., 1996] (Figure 5). Alternatively, Mesozoic subsidence in the outer proximal margin may be similar to that in the Grand Banks area. Here, discrete extensional episodes or rift pulses [e.g., Sinclair, 1995], occurring diachronously in distinct segments of the Newfoundland margin, add up to the final values of basement subsidence recorded in adjacent sedimentary basins [e.g., Hiscott et al., 1990a].

[53] A third explanation incorporates the Oxfordian-Kimmeridgian subsidence recorded in the inner proximal margin, with a shift in the locus of extension toward the outer proximal during the Late Jurassic, in a process similar to that recorded in the Peniche Basin [Alves et al., 2006] (Figures 13 and 16). The data in this paper confirm that outer proximal basins were structurally independent from the inner proximal margin during the last extension episode in southwest Iberia (rift 3). Therefore, latest Jurassic-Early Cretaceous continental breakup west of the study area [Pinheiro et al., 1992; Srivastava et al., 2000] must have been immediately preceded by significant extension in the outer proximal margin during the advanced rifting stage (Figures 15 and 16). Comparatively, after a peak in subsidence around the Oxfordian-Kimmeridgian boundary [Wilson et al., 1989; Hiscott et al., 1990a], the Lusitanian Basin and Santiago do Cacém areas record a widespread sea level fall during the late Kimmeridgian [Inverno et al., 1993]. No major subsidence pulse is recorded in the two latter regions by the time rift 4 was developing in the Peniche Basin [Alves et al., 2006; Inverno et al., 1993; Dinis et al., 2008]. These latter considerations indicate that subsidence in parts of the outer proximal margin of southwest Iberia results from the superposition of discrete extensional episodes, particularly those related to OxfordianKimmeridgian rifting in the inner proximal basins and to a principal latest Kimmeridgian-earliest Cretaceous pulse of subsidence, related to a shift in the principal locus of extension toward the outer proximal margin (Figures 13 and 16). Thus, the study area could comprise synrift successions spanning at least the middle Oxfordian-latest Tithonian ( $\sim 158$ to $147 \mathrm{Ma}$ ), perhaps extending to the Valanginian (134 Ma) toward the northern part of the Tagus Abyssal Plain (Figure 1b). Also, basin-bounding faults on the outer proximal margin, including the SFS, should have been generated prior to rift 3 and rift 4, thus accounting for (1) the thickness variations observed in Triassic-Middle Jurassic strata along west Iberia and (2) variations in the distribution of Triassic-Hettangian salt on the west Iberian margin, where regions with thick evaporites in depth (and developed salt structures) alternate with regions with scarce or no evaporites [Alves et al., 2006] (Figure 13). Such an explanation implies that (1) the models of Froitzheim and Manatschal [1996] for the Tethyan Ocean are not fully applicable to the outer proximal basins of west Iberia and (2) the final episodes of extension leading to breakup, rift 3 in southwest Iberia and rift 4 in the Peniche Basin, were preceded by significant prerift subsidence and extensional faulting on the outer proximal margin (Figures 13 and 16).

\subsection{Inferred Hydrocarbon Plays in West Iberia}

[54] The timing and magnitude of basement subsidence along west Iberia are of crucial importance to the hydrocarbon potential of the outer proximal basins. The occurrence of productive source rock intervals depends on the relative depths of burial (hence, relative basement subsidence) and subsequent tectonic uplift experienced by prerift 
and synrift strata [Biddle and Wielchowsky, 1994]. Potential source rocks in Earliest Jurassic and Late Jurassic successions in the Lusitanian Basin [GPEP, 1996; also unpublished report, 1986] may occur in outer proximal basins at favorable depths (Figure 17). In southwest Iberia successive extensional episodes, probably lasting from the late Callovian?-Oxfordian to the latest Tithonian/Berriasian, may have also contributed to the accumulation of thick source rock intervals within synrift strata. Furthermore, geochemical analyses of outcropping Paleozoic strata, potentially comprising basement units offshore Alentejo show good source rock potential, in particular marine Carboniferous and Silurian black shales. Silurian shales exhibit TOC peak values of 4 and a mean vitrinite reflectance of 2 (wet gas to dry gas windows). Carboniferous shales have vitrinite reflectance values of up to 0.7 , well within the oil window [GPEP, 1996].

[55] The principal issues when considering the hydrocarbon potential of west Iberia relate to (1) the marked structural segmentation of deep offshore basins, with discrete tilt blocks comprising individual depocenters recording distinct subsidence histories; (2) the different timing of synrift successions, particularly the variations in subsidence maxima across different segments of the margin; and (3) the location of the main axes of prerift extension. For instance, basal synrift units deposited in the Lusitanian Basin during rift 3, known to have source rock potential [e.g., Wilson et al., 1989; Rasmussen et al., 1998], should not occur within deep offshore basins of segments 2 to 4 or, instead, their tectonosedimentary expression should relate to a prerift stage rather than to the last episode of basement subsidence recorded on the outer proximal margin (Figure 8). Alternatively, multiphased rifting along the west Iberian margin might contribute to the stacking of two or more synrift intervals in subbasins affected by a number of Late Jurassic-Cretaceous extensional episodes, thus increasing the potential for finding source rock intervals in deep offshore basins (e.g., Figure 4) [Alves et al., 2006]. Also, the complex segmentation of the west Iberian margin may partly result from early episodes of continental rifting, thus creating the necessity of identifying the location of the principal Triassic-Middle Jurassic depocenters west of the SFS to better assess the hydrocarbon potential of west Iberia.

[56] The interpreted data confirms that overburden shortening is relatively limited $(<10 \%)$ in southwest Iberia. More importantly, Cenozoic inversion did not hinder the deposition of thick postrift successions, particularly west of the SFS (Figure 17). In addition, extensive (mud-rich) seal units may comprise great part of the postrift strata offshore southwest Iberia, a character that contrasts with large parts of the Peniche Basin [Alves et al., 2006] (Figure 17). These observations may have implications for the hydrocarbon potential the distinct crustal segments considered in this paper. The maturation history of oil sampled in the Lusitanian Basin indicates that fault-controlled fluid migration and overburden exhumation were caused by crustal uplift and overburden reactivation after the early rift-related stages of oil play development [Masson and Miles, 1986; GPEP, unpublished report, 1986].

[57] As in the Peniche Basin, Cenozoic compressional episodes generated structural traps and eventually generated new migration paths for hydrocarbon generated from Mesozoic source rocks [Wilson et al., 1989; GPEP, unpublished report, 1986]. In the study area, Cenozoic tectonism was responsible for (1) reactivation of rift-related normal faults as backthrusts and (2) forced folding of the late MesoCenozoic overburden against buttress structures such as seamounts and adjacent footwalls to rotated listric blocks, forming gentle anticlines in rift-related half grabens (Figures 8 and 17). Some of the structures observed at depth, particularly those related to Mesozoic extension, broaden the range of potential structural traps existing on the margin. This is the case of low-angle folds induced by differential compaction, fault-related roll-over anticlines and stratigraphic traps in synrift and postrift units. The absence of significant exhumation on the outer proximal margin also favors source rock maturation and reservoir rock preservation. Consequently, large Mesozoic subbasins blanketed by relatively thick Cenozoic strata show the greater potential for oil play generation.

\section{Conclusions}

[58] This work proves the existence of north striking sedimentary basins with developed synrift strata in southwest Iberia. The main conclusions of this paper are:

[59] 1. The Alentejo Basin comprises six (6) principal depocenters delimited by a slope-bounding fault system (SFS). Tilt blocks with scarce (if any) Triassic-earliest Jurassic evaporites are observed west of the SFS.

[60] 2. Basement subsidence continued during the latest Kimmeridgian/Tithonian in continental slope basins, as shown by developed synrift strata on the outer proximal margin deposited just below the regional breakup unconformity. It was preceded by Triassic-Middle Jurassic extension as shown by the presence of thick $(>1.0 \mathrm{~s}$ twtt) prerift units on the outer proximal margin.

[61] 3. Synrift subsidence (rift 3) in the study area was followed by latest Jurassic-Early Cretaceous continental breakup. Continental rifting west of the Lusitanian Basin started in the latest Jurassic (late Kimmeridgian-Tithonian) and during the late Berriasian/Valanginian in segment 4.

[62] 4. Regressive episodes and their basal unconformities, associated with tectonic uplift in inner proximal basins, can be used to date synrift extension in deep offshore basins.

[63] 5. Five regional unconformities (S1 to S5) and related regression episodes therefore reflect major tectonic events occurring on the deeper margin. They reveal the development of two principal Oxfordian-Aptian rift axes in west Iberia. Separating these two axes are marginal horsts west of the Lusitanian Basin (Berlengas Horst and its continuation toward the Aveiro High [Alves et al., 2006]), and an inferred west to northwest trending lineament marking the edge of continental slope basins southwest of Lisbon and Estremadura. 
[64] The Manatschal and Bernoulli [1999] evolution stages for nonvolcanic rift margins, recognized offshore Galicia and on the ancient Adria margin, are valid for the southwest Iberia. As in the Peniche Basin [Alves et al., 2006], synrift subsidence shifted westward and northward during the Late Jurassic-earliest Cretaceous, resulting in erosion of a significant portion of the inner proximal margin. Thus, three main regions can be identified on the lower plate margin of southwest Iberia on the basis of their distinct structural and depositional evolution: (1) an inner proximal margin where synrift successions are relatively thin, shallow water carbonate deposition prevailed throughout the Jurassic, and no major subbasins have been formed; (2) an outer proximal margin coincident with the modern continental slope area, in which where thick synrift strata have been deposited; and (3) a distal margin where the western limit of rift-related basins and the ocean-continent transition zone exist. The SFS controlled the progradation of continental slope units during the Cretaceous-early Cenozoic, and the deposition of Cenozoic units on the outer proximal margin. This demonstrates that the morphology of a lower plate margin is established during the rifting episodes leading to continental break up, i.e., during the advanced rifting stage of Manatschal and Bernoulli [1998, 1999].

[65] Acknowledgments. TGS/NOPEC-Geophysical Company, T. Abecasis, and the DPEP-Divisão para a Pesquisa e Exploração de Petróleo are acknowledged for permitting the use of seismic and well data on the shallow offshore basins. We thank Mary Ford, two anonymous reviewers, and the Associate Editor Carlo Doglioni for their constructive comments. J. Cartwright is acknowledged for reviewing a final draft of the manuscript. This work was funded by the Fundação para a Ciência e Tecnologia (BPD 6116-2001 and Program INGMAR) and by the European Social Fund (ESF) through the 3rd EU Framework Program.

\section{References}

Acocella, V., B. Abebe, T. Korme, and F. Barberi (2008), Structure of Tendaho Graben and Manda Hararo Rift: Implications for the evolution of the southern Red Sea propagator in central Afar, Tec tonics, 27, TC4016, doi:10.1029/2007TC002236.

Afilhado, A., L. Matias, H. Shiobara, A. Hirn, L. Mendes-Victor, and H. Shimamura (2008), From unthinned continent to ocean: The deep structure of the West Iberia passive continental margin at $38^{\circ} \mathrm{N}$, Tectonophysics, 458, 9-50, doi:10.1016/j.tecto.2008.03.002.

Alves, T. M. (2002), Salt vs. fault tectonics on the western Iberian margin, Portugal: Controls on Meso-Cenozoic depositional systems, Ph.D. thesis, 386 pp., Univ. of Manchester, Manchester, U. K.

Alves, T. M., R. L. Gawthorpe, D. H. Hunt, and J. H. Monteiro (2002), Jurassic tectono-sedimentary evolution of the Northern Lusitanian Basin (offshore Portugal), Mar. Pet. Geol., 19, 727-754, doi:10.1016/S0264-8172(02)00036-3.

Alves, T. M., R. L. Gawthorpe, D. H. Hunt, and J. H. Monteiro (2003a), Cenozoic tectono-sedimentary evolution of the western Iberian margin, Mar Geol., 195, 75-108, doi:10.1016/S00253227(02)00683-7.

Alves, T. M., G. Manuppella, R. L. Gawthorpe, D. H. Hunt, and J. H. Monteiro (2003b), The depositional evolution of diapir- and fault-bounded rift basins: Examples from the Lusitanian Basin of west Iberia Sediment. Geol., 162, 273-303, doi:10.1016/ S0037-0738(03)00155-6.

Alves, T. M., G. Manuppella, R. L. Gawthorpe, D. H Hunt, and J. H. Monteiro (2003c), Post-Jurassic tectono-sedimentary evolution of the Northern Lusitanian Basin (western Iberian margin), Basin Res., 15, 227-249, doi:10.1046/j.1365-2117. 2003.00202.x.

Alves, T. M., C. Moita, F. Sandnes, T. Cunha, J. H. Monteiro, and L. M. Pinheiro (2006), MesozoicCenozoic evolution of North Atlantic continentalslope basins: The Peniche basin, western Iberian margin, AAPG Bull., 90, 31-60, doi:10.1306/ 08110504138 .

Atrops, F., and B. Marques (1986), Mise en évidence de la zone à platynota (Kimméridgien inférieur) dans le massif du Montejunto (Portugal); consequences stratigraphiques et paléontologiques, Geobios, 19, 537-547, doi:10.1016/S00166995(86)80053-5.
Baldy, P. (1977), Géologie du plateau continental portugais (au sud du Cao de Sines), Thèse 2è cycle, 113 pp., Univ. P. et M. Curie, Paris.

Biddle, K. T., and C. C. Wielchowsky (1994), Hydrocarbon traps, in The Petroleum System-From Source to Trap, edited by L. B. Magoon and W. G. Dow, AAPG Mem., 60, 219-235.

Boillot, G., and N. Froitzheim (2001), Non-volcanic rifted margins, continental break-up and the onset of sea-floor spreading: Some outstanding questions, in Non-volcanic Continental Margins: A Comparison of Evidence From Land and Sea, edited by R. C. L. Wilson et al., Geol. Soc. Spec. Publ., 187, 9-30.

Boillot, G. J., and E. L. Winterer (1988), Drilling on the Galicia Margin: Restrospect and prospect, Proc. Ocean Drill. Program Sci. Results, 103 , $809-828$.

Boillot, G., J. Girardeau, and E. L. Winterer (1989), Rifting processes of the west Galicia margin, Spain, in Extensional Tectonics and Stratigraphy of the North Atlantic Margins, edited by A. J. Tankard and H. R. Balkwill, AAPG Mem., 40, $363-377$.

Boillot, G., M. O. Beslier, C. M. Krawczyk, D. Rappin, and T. J. Reston (1995), The formation of passive margins: Constraints from the crustal structure and segmentation of the deep Galicia margin, Spain, in The Tectonics, Sedimentation and Palaeoceano graphy of the North Atlantic Ocean, edited by R. A. Scrutton et al., Geol. Soc. Spec. Publ., 90, $71-91$.

Bueno, G. V. (2004), Event diachronism in the South Atlantic rift, Bull. Geocienc. Petrobras, 14, $203-$ 229

Canérot, J., J. Rey, R. Baptista, G. Manuppella, and B. Peybernès (1995), Nouvelle interprétation structurale et géodynamique de la marge atlantique portugaise dans le secteur de Caldas da Rainha (Portugal), C. R. Acad., Sci., 320, 523-530.

Clark, S. A., D. S. Sawyer, J. A. Austin Jr., G. L. Christeson, and Y. Nakamura (2007), Characterizing the Galicia Bank-southern Iberia Abyssal Plain rifted margin segment boundary using multichannel seismic and ocean bottom seismomete data, J. Geophys. Res., 112, B03408, doi:10.1029/ 2006JB004581.

Coppier, G., and D. Mougenot (1982), Stratigraphie sismique et évolution géologique des formations néogènes et quaternaries de la plate-forme conti- nentale portugaise au Sud de Lisbonne, Bull. Soc. Geol. Fr. 24, $421-431$

Dinis, J. L., J. Rey, P. P. Cunha, and P. Callapez (2008), Stratigraphy and allogenic controls of the western Portugal Cretaceous: An updated synthesis, Cretaceous Res., 29, 772-780, doi:10.1016/j. cretres.2008.05.027.

Driscoll, N. W., J. R. Hogg, N. Christie-Blick, and G. D. Karner (1995), Extensional tectonics in the Jeanne d'Arc Basin, offshore Newfoundland: Implications for the timing of break-up between Grand Banks and Iberia, in The Tectonics, Sedimentation and Palaeoceanography of the North Atlantic Region, edited by R. A. Scrutton et al., Geol. Soc. Spec. Publ., 90, 1-28.

Froitzheim, N., and G. Manatschal (1996), Kinematics of Jurassic rifting, mantle exhumation, and passivemargin formation in the Austroalpine and Penninic nappes (eastern Switzerland), Geol. Soc. Am. Bull., 108, 1120-1133, doi:10.1130/0016-7606(1996) 108<1120:KOJRME $>2.3$.CO;2

Gabinete para a Pesquisa e Exploração de Petróleo (GPEP) (1996), Porto and Lusitanian Basins, Geochemical Analyses BEICIP-FRANLAB: Contribution to the MILUPOBAS Project, EC Contract JOU2-CT94-0348, 9 vols., Lisbon.

Gradstein, S., F. P. Agterberg, J. G. Ogg, J. Hardenbol, P. van Veen, J. Thierry, and Z. Huang (1995), A Triassic, Jurassic and Cretaceous time scale, in Geochronology, Time Scales and Global Stratigraphic Correlation, edited by W. A. Berggren et al., Spec. Publ. SEPM Soc. Sediment., 54, 95-126.

Groupe Galice (1979), The continental margin off Galicia and Portugal: Acoustical stratigraphy, dredge stratigraphy and structural evolution, Initial Rep. Deep Sea Drill. Proj., 47, 633-662.

Harding, T. P. (1985), Seismic characteristics and identification of negative flower structures, positive flower structures, and positive structural inversion, AAPG Bull., 69, 582-600.

Hill, G. (1989), Distal alluvial fan sediments from the Upper Jurassic of Portugal: Controls on their cyclicity and channel formation, J. Geol. Soc., 146, 539-555, doi:10.1144/gsigs.146.3.0539.

Hiscott, R. N., R. C. L. Wilson, F. M. Gradstein, V. Pujalte, J. Garcia-Mondejar, R. R. Boudreau, and H. A. Wishart (1990a), Comparative stratigraphy and subsidence history of Mesozoic rift basins of North Atlantic, AAPG Bull., 74, 60-76.

Hiscott, R. N., R. C. L. Wilson, S. C. Harding, V. Pujalte, and D. Kitson (1990b), Contrasts in 
Early Cretaceous depositional environments of marine sandbodies, Grand Banks - Iberian corridor, Bull. Can. Pet. Geol., 38, 203-214.

Hubbard, R. J., J. Pape, and D. G. Roberts (1985), Depositional sequence mapping to illustrate the evolution of a passive continental margin, $A A P G$ Mem., 39, 93-115.

Inverno, C., G. Manuppella, G. Zbyszewski, J. Pais, and M. L. Ribeiro (1993), Notícia explicativa da carta geológica 1:50000 42C-Santigo do Cacém, 46 pp., Serv. Geol., Lisbon, Portugal.

Jansa, L. F., J. P. Bujak, and G. L. Williams (1980), Upper Triassic salt deposits of the western North Atlantic, Can. J. Earth Sci., 17, 547-559.

Khalil, S. M., and K. R. McClay (2001), Tectonic evolution of the NW Red Sea-Gulf of Suez rift system, in Non-volcanic Continental Margins: Comparison of Evidence From Land and Sea, edited by R. C. L. Wilson et al., Geol. Soc. Spec. Publ., 187, 453-473.

Kinabo, B. D., J. P. Hogan, E. A. Atekwana, M. G. Abdelsalam, and M. P. Modisi (2008), Fault growth and propagation during incipient continental rifting: Insights from a combined aeromagnetic and Shuttle Radar Topography Mission digital elevation model investigation of the Okavango Rift Zone, northwest Botswana, Tectonics, 27, TC3013, doi:10.1029/2007TC002154.

Leinfelder, R. R., and R. C. L. Wilson (1998), Thirdorder sequences in an Upper Jurassic rift-related second-order sequence, central Lusitanian Basin, Portugal, in Mesozoic and Cenozoic Sequence Stratigraphy of European Basins, edited by P. C. Graciansky et al., Spec. Publ. SEPM Soc. Sediment., 60, 507-525.

Lister, G. S., M. A. Etheridge, and P. A. Symonds (1986), Detachment faulting and the evolution of passive continental margins, Geology, 14, 246-250, doi:10.1130/0091-7613(1986)14<246:DFATEO> 2.0. $\mathrm{CO} ; 2$.

Lister, G. S., M. Etheridge, and P. Symonds (1991), Detachment models for the formation of passive continental margins, Tectonics, 10, 1038-1064, doi:10.1029/90TC01007.

Manatschal, G. (2004), New models for evolution of magma-poor rifted margins based on a review of data and concepts from West Iberia and the Alps, Int. J. Earth Sci., 93, 432-466, doi:10.1007/ s00531-004-0394-7.

Manatschal, G., and D. Bernoulli (1998), Rifting and early evolution of ancient ocean basins: The record of the Mesozoic Tethis and of the GaliciaNewfoundland margins, Mar. Geophys. Res., 20 371 - 381, doi:10.1023/A:1004459106686.

Manatschal, G., and D. Bernoulli (1999), Architecture and tectonic evolution of non-volcanic margins: Present day Galicia and ancient Adria, Tectonics, 18, 1099-1119, doi:10.1029/1999TC900041.

Masson, D. G., and P. R. Miles (1986), Development and hydrocarbon potential of Mesozoic sedimentary basins around margins of the North Atlantic, AAPG Bull., 70, 721-729.

Mauffret, A., D. Mougenot, P. R. Miles, and J. A Malod (1989a), Cenozoic deformation and Mesozoic abandoned spreading centre in the Tagus Abyssal Plain (west of Portugal): Results of a multichannel seismic survey, Can. J. Earth Sci., 26 , 1101-1123, doi:10.1139/e89-095.

Mauffret, A., D. Mougenot, P. R. Miles, and J. A. Malod (1989b), Results from the Multichannel Reflection Profiling of the Tagus Abyssal Plain (Portugal); Comparison with the Canadian margin, in Extensional Tectonics and Stratigraphy of the North Atlantic Margins, edited by A. J. Tankard and H. R. Balkwill, AAPG Mem., 40, 379-393.

Michon, L., and O. Merle (2003), Mode of lithospheric extension: Conceptual models from analogue modeling, Tectonics, 22(4), 1028, doi:10.1029/ 2002 TC001435.

Mitchum, R. M., P. R. Vail, and J. B. Sangree (1977), Seismic stratigraphy and global changes in sea level. Part 6. Stratigraphic interpretation of seismic reflection patterns in depositional sequences, $A A P G$ Mem., 26, 117-133.

Mougenot, D., J. H. Monteiro, P. A. Dupeuble, and J. A. Malod (1979), La marge continentale SudPortugais: Evolution structurale et sédimentaire, Cienc. Terra Lisboa, 5, 223-246.

Mougenot, D., R. B. Kidd, A. Mauffret, H. Regnauld, R. G. Rothwell, and J.-R. Vanney (1984), Geological interpretation of combined SEABEAM, GLORIA and seismic data from Porto and Vigo seamounts, Iberian continental margin, Mar. Geo phys. Res., 6, 329-363, doi:10.1007/BF00286249.

Murillas, J., D. Mougenot, G. Boillot, M. C. Comas, E. Banda, and A. Mauffret (1990), Structure and evolution of the Galicia Interior basin (Atlantic western Iberian continental margin), Tectonophysics, 184, 297-319, doi:10.1016/0040 1951(90)90445-E.

Neves, M. C., P. Terrinha, A. Afilhado, M. Moulin, L. Matias, and F. Rosas (2009), Response of a multi-domain continental margin to compression: Study from seismic reflection-refraction and numerical modelling in the Tagus Abyssal Plain, Tec tonophysics, 468(1-4), 113-130, doi:10.1016 j.tecto.2008.05.008

Péron-Pinvidic, G., G. Manatschal, T. Minshull, and D. Sayer (2007), Tectonosedimentary evolution of the deep Iberia-Newfoundland margins: Evidence for a complex breakup history, Tectonics, 26 , TC2011, doi:10.1029/2006TC001970.

Pinheiro, L. M., R. B. Whitmarsh, and P. R. Miles (1992), The ocean-continent transition off the western continental margin off Iberia. Part II. Crusta structure in the Tagus Abyssal Plain, Geophys. J. Int., 109, $106-124$, doi: $10.1111 / \mathrm{j} .1365$ 246X.1992.tb00082.x.

Pinheiro, L. M., R. C. L. Wilson, R. P. Reis, R. B. Whitmarsh, and A. Ribeiro (1996), The western Iberian margin: A geophysical and geological over view, Proc. Ocean Drill. Program Sci. Results, $149,3-23$

Prosser, S. (1993), Rift-related linked depositional systems and their seismic expression, in Tectonics and Seismic Stratigraphy, edited by G. D. Williams and A. Dobb, Geol. Soc. Spec. Publ., 71, 35-66.

Ramalho, M. M. (1971), Contribution a l'etude micropaleontologique et stratigraphique du Jurassique superieur et du Cretace inferieur des environs de Lisbonne (Portugal), Mem. 19, 212 pp., Serv. Geol. Portugal, Lisbon.

Rasmussen, E. S., S. Lomholt, C. Andersen, and O. V. Vejbæk (1998), Aspects of the structural evolution of the Lusitanian Basin in Portugal and the shelf and slope area offshore Portugal, Tectonophysics, $300,199-255$, doi: $10.1016 / \mathrm{S} 0040$ 1951(98)00241-8

Ravnås, R., J. Windelstad, D. Mellere, A. Nøttvedt, T. S. Sjoblom, R. J. Steel, and R. C. L. Wilson (1997), A marine Late Jurassic syn-rift succession in the Lusitanian Basin, western Portugal-tectonic significance of stratigraphic signature, Sediment Geol., 114, 237-266, doi:10.1016/S0037 0738(97)00068-7.

Réhault, J.-P., and A. Mauffret (1979), Relations between tectonics and sedimentation around the northwestern Iberian margin, Initial Rep. Deep Sea Drill. Proj., 47, 663-681.

Reston, T. J., and M. Pérez-Gussinyé (2007), Lithospheric extension from rifting to continental breakup at magma-poor margins: Rheology, serpentinisation and symmetry, Int. J. Earth Sci., 96 1033-1046, doi:10.1007/s00531-006-0161-z.

Reston, T. J., C. M. Krawczyk, and H.-J. Hoffmann (1995), Detachment tectonics during Atlantic rifting: Analysis and interpretation of the $\mathrm{S}$ reflection, the west Galicia margin, in The Tectonics, Sedimentation and Palaeoceanography of the North Atlantic Ocean, edited by R. A. Scrutton et al., Geol. Soc. Spec. Publ., 90, 93-109.

Rey, J., J. L. Dinis, P. Callapez, and P. P. Cunha (2006), Da rotura continental à margem passive. Composi- ção e evolução do Cretácico de Portugal, Cadernos 90, 75 pp., Geol. do Inst. Geol. Mineiro, Lisbon.

Ribeiro, A., M. C. Kullberg, J. C. Kullberg, G. Manuppella, and S. Phipps (1990), A review of Alpine tectonics in Portugal: Foreland detachment in basement and cover rocks, Tectonophysics, 184, 357-366, doi:10.1016/0040-1951(90) 90448-H

Roca, E., M. Sans, and H. A. Koyi (2006), Polyphase deformation of diapiric areas in models and in the eastern Prebetics (Spain), AAPG Bull., 90, $115-$ 136, doi:10.1306/07260504096.

Sayers, J., P. A. Symonds, N. G. Direen, and G. Bernardel (2001), Nature of the continent-ocean transition on the non-volcanic rifted margin of the Great Australian Bight, in Non-volcanic Continen tal Margins: A Comparison of Evidence From Land and Sea, edited by R. C. L. Wilson et al., Geol. Soc. Spec. Publ., 187, 51-76.

Shipboard Scientific Party (2004), Leg 210 preliminary report, Ocean Drill. Program Prelim. Rep., 110, $62 \mathrm{pp}$

Sinclair, I. K. (1995), Sequence stratigraphic response to Aptian-Albian rifting in conjugate margin basins: A comparison of the Jeanne d'Arc Basin, offshore Newfoundland, and the Porcupine Basin, offshore Ireland, in The Tectonics, Sedimentation and Palaeoceanography of the North Atlantic Ocean, edited by R. A. Scrutton et al., Geol. Soc Spec. Publ., 90, 29-49.

Srivastava, S. P., J. C. Sibuet, S. Cande, W. R. Roest, and I. D. Reid (2000), Magnetic evidence for slow seafloor spreading during the formation of the Newfoundland and Iberian margins, Earth Planet Sci. Lett., 182, 61-76, doi:10.1016/S0012 $821 \mathrm{X}(00) 00231-4$

Stapel, G., S. Cloething, and B. Pronk (1996), Quantitative subsidence analysis of the Mesozoic evolution of the Lusitanian basin (western Iberian margin), Tectonophysics, 266, 493-507, doi:10.1016/S0040-1951(96)00203-X.

Tankard, A. J., and H. J. Welsink (1987), Extensiona tectonics and stratigraphy of the Hibernia Oil field, Grand Banks, Newfoundland, AAPG Bull., 71 , $1210-1232$.

Tankard, A. J., H. J. Welsink, and W. A. M. Jenkins (1989), Structural styles and stratigraphy of the Jeanne d'Arc basin, Grand Banks of Newfound land, in Extensional Tectonics and Stratigraphy of the North Atlantic Margins, edited by A. J. Tankard and H. R. Balkwill, AAPG Memoir, 40, 265-264.

Terrinha, P. A. G. (1998), Structural geology and tectonic evolution of the Algarve Basin, Ph.D. thesis, 430 pp., Univ. of London, London.

Terrinha, P., et al. (2003), Tsunamigenic-seismogenic structures, neotectonics, sedimentary processes and slope instability on the southwest Portuguese Margin, Mar. Geol., 195, 55-73, doi:10.1016/S0025 3227(02)00682-5.

Thinon, I., J.-P. Réhault, and L. Fidalgo-Gonzáles (2002), The syn-rift sedimentary cover of the North Biscay Margin (Bay of Biscay): From new reflection seismic data, Bull. Soc. Geol. Fr. 173, $515-$ 522, doi:10.2113/173.6.515

Tucholke, B. E., and J.-C Sibuet (2007), Leg 210 synthesis: Tectonic, magmatic, and sedimentary evolution of the Newfoundland-Iberia rift, Proc Ocean Drill. Program Sci. Results, 210, 1-56.

Tucholke, B. E., and R. B. Whitmarsh (2009), The Newfoundland-Iberia conjugate rifted margins, in Principles of Phanerozoic Regional Geology, edited by A. W. Bally and D. G. Roberts, Elsevier, Amsterdam, in press.

Welsink, H., and A. Tankard (2009), Extensional tectonics and stratigraphy of the Mesozoic Jeanne d'Arc basin, Grand Banks of Newfoundland, in Principles of Phanerozoic Regional Geology, edited by A. W. Bally and D. G. Roberts, Elsevier, Amsterdam, in press.

Wernicke, B. (1985), Uniform sense normal simple shear of the continental lithosphere, Can. J. Earth Sci., 22, 108-125. 
Whitmarsh, R. B., and P. R. Miles (1995), Models of the development of the West Iberia rifted continental margin at $40^{\circ} 30^{\prime} \mathrm{N}$ deduced from surface an deep-tow magnetic anomalies, J. Geophys. Res. 100, 3789-3806, doi:10.1029/94JB02877.

Whitmarsh, R. B., P. R. Miles, J.-C. Sibuet, and V. Louvel (1996), Geological and geophysical implications of deep-tow magnetometer observations near ODP sites $897,898,900$, and 901 on the West Iberia continental margin, Proc. Ocean Drill. Program Sci. Results, 149, 665-674.

Whitmarsh, R. B., T. A. Minshull, S. M. Russell, S. M. Dean, K. E. Louden, and D. Chian (2001), The role of syn-rift magmatism in the rift-to-drift evolution of the West Iberia continental margin: Geophysical observations, in Non-volcanic Continental Margins: A Comparison of Evidence From Land and Sea, edited by R. C. L. Wilson et al., Geol. Soc Spec. Publ., 187, 107-124.

Williams, B. P. J., P. M. Shannon, and I. K. Sinclair (1999), Comparative Jurassic and Cretaceous tectono-stratigraphy and reservoir development in the Jeanne d'Arc and Porcupine basins, in Petroleum Geology of Northwest Europe: Proceedings of the 5th Conference, edited by A. J. Fleet and S. A. R. Boldy, pp. 487-499, Geol. Soc., London.

Wilson, R. C. L., R. N. Hiscott, M. G. Willis, and F. M. Gradstein (1989), The Lusitanian basin of westcentral Portugal: Mesozoic and Tertiary tectonic, stratigraphy, and subsidence history, in Extensional Tectonics and Stratigraphy of the North Atlantic Margins, edited by A. J. Tankard and H. R. Balkwill, AAPG Mem., 40, 341-361.

Wilson, R. C. L., D. S. Sawyer, R. B. Whitmarsh, J. Zerong, and J. Carbonell (1996), Seismic stratigraphy and tectonic history of the Iberia Abyssa Plain, Proc. Ocean Drill. Program Scientific Results, 149, $617-630$

Wilson, R. C. L., G. Manatschal, and S. Wise (2001), Rifting along non-volcanic passive margins: Stratigraphic and seismic evidence from the Mesozoic successions of the Alps and western Iberia, in Nonvolcanic Continental Margins: A Comparison of Evidence From Land and Sea, edited by R. C. L. Wilson et al., Geol. Soc. Spec. Publ., 187, 429452 .

Withjack, M. O., R. W. Schlische, and P. E. Olsen (1998), Diachronous rifting, drifting, and inversion on the passive margin of central eastern North America; an analog for other passive margins, AAPG Bull., 82, 817-835.

T. M. Alves, 3DLab, School of Earth, Ocean and Planetary Sciences, Main Building, Park Place, Cardiff University, Cardiff, CF10 3YE, UK. (alvest@cardiff. ac.uk)

T. Cunha, Department of Earth Sciences, Oxford University, Parks Road, Oxford OX1 3PR, UK

C. Moita, Direcção Geral de Energia e Geologia, Divisão para a Pesquisa e Prospecção de Petróleo, Avenida República 45-5 $5^{\circ}$, Lisbon, Portugal.

J. H. Monteiro, Departamento de Geologia Marinha, Instituto Nacional de Engenharia, Tecnologia Inovação, Estrada da Portela, Zambujal-Alfragide, P-2720-866 Amadora, Portugal.

R. Myklebust and M. Ullnaess, TGS-NOPEC Geophysical Company, Hagaløkkveien 13, N-1383 Asker, Norway. 